NBER WORKING PAPER SERIES

\title{
LOSING HEART? \\ THE EFFECT OF JOB DISPLACEMENT ON HEALTH
}

\author{
Sandra E. Black \\ Paul J. Devereux \\ Kjell G. Salvanes \\ Working Paper 18660 \\ http://www.nber.org/papers/w18660 \\ NATIONAL BUREAU OF ECONOMIC RESEARCH \\ 1050 Massachusetts Avenue \\ Cambridge, MA 02138 \\ December 2012
}

We thank participants of seminars at Uppsala University, Norwegian School of Economics, IZA, Royal Holloway, and the Bergen-Stavanger Workshop for their helpful comments. The authors thank the Norwegian research council for financial support, and Devereux thanks the Irish Research Council for the Humanities and Social Sciences (IRCHSS) for financial support. We thank the Norwegian National Health Institute for providing us with the health data, and, in particular, Kjersti Andersen Nerhus, Inger Cappelen, and Sidsel Graff-Iversen for very helpful discussions about interpreting the data. The views expressed herein are those of the authors and do not necessarily reflect the views of the National Bureau of Economic Research.

NBER working papers are circulated for discussion and comment purposes. They have not been peerreviewed or been subject to the review by the NBER Board of Directors that accompanies official NBER publications.

(C) 2012 by Sandra E. Black, Paul J. Devereux, and Kjell G. Salvanes. All rights reserved. Short sections of text, not to exceed two paragraphs, may be quoted without explicit permission provided that full credit, including (C) notice, is given to the source. 
Losing Heart? The Effect of Job Displacement on Health

Sandra E. Black, Paul J. Devereux, and Kjell G. Salvanes

NBER Working Paper No. 18660

December 2012

JEL No. I10,J63

\begin{abstract}
$\underline{\text { ABSTRACT }}$
Job reallocation is considered to be a key characteristic of well-functioning labor markets, as more productive firms grow and less productive ones contract or close. However, despite its potential benefits for the economy, there are significant costs that are borne by displaced workers. We study how job displacement in Norway affects cardiovascular health using a sample of men and women who are predominantly aged in their early forties. To do so we merge survey data on health and health behaviors with register data on person and firm characteristics. We track the health of displaced and non-displaced workers from 5 years before to 7 years after displacement. We find that job displacement has a negative effect on the health of both men and women. Importantly, much of this effect is driven by an increase in smoking behavior. These results are robust to a variety of specification checks.
\end{abstract}

Sandra E. Black

Department of Economics

University of Texas

Austin, TX 78712

and IZA and NBER

sblack@austin.utexas.edu

Paul J. Devereux

School of Economics

and Geary Institute

University College Dublin

Belfield, Dublin 4

Ireland

and IZA and CEPR

devereux@ucd.ie
Kjell G. Salvanes

Department of Economics

Norwegian School of Economics

Hellev. 30, N-5035 Bergen

Norway

and IZA and CEP

kjell.salvanes@nhh.no 


\section{Introduction}

Job reallocation is considered to be a key characteristic of well-functioning labor markets, as more productive firms grow and less productive ones contract or close. However, despite its potential benefits for the economy, there are significant costs that are borne by displaced workers. While a large literature focuses on income losses from displacement, much less is known about the health impacts of these types of job loss. This issue is particularly salient given the large increases in unemployment that have occurred over the last few years during the economic downturns.

There are several mechanisms through which job displacement may affect health. Job displacement increases stress, which is known to have negative effects on cardiovascular health. However, there is little evidence on the link between specific causes of stress, such as changes in employment status or earnings losses, and cardiovascular health. ${ }^{1}$ Changes in income induced by displacement could also affect consumption patterns, which could have either a positive or negative effect on health. For example, a person may respond to the reduction in income by reducing consumption of cigarettes and alcohol or, in contrast, by reducing consumption of fresh fruit and vegetables. Finally, changes in employment status that accompany displacement may affect time spent on exercise and, in this way, impact health.

In this paper, we examine how job displacement in Norway affects cardiovascular health directly using a sample of men and women who are predominantly in their early forties. Our unique dataset merges registry data on the population of Norway with newly available representative survey data on health and health behaviors. Using plant identifiers, we determine which employees lose their jobs due to plant closings or mass layoffs and track the health of displaced and non-displaced workers from 5 years before to 7 years after

\footnotetext{
${ }^{1}$ See Bosma, Siegrist and Marmot (1998) and Kirvimaki et al. (2002) for evidence.
} 
displacement. We focus on the effect of displacement on heart-related variables (cholesterol, blood pressure, smoking, body mass index) as well as on two indices that measure the risk of heart disease. Our focus on heart-related variables relates both to the data available to us but also to the importance of heart-related conditions -- cardiovascular disease (CVD) is a growing problem throughout the world; in the United States alone, more people die from CVD than from cancer, and heart disease is a major risk for people aged 40 and above.

Our work has a number of advantages over existing work. We observe the population of Norway, so we are able to follow a large number of displaced workers including those leaving the labor force. In addition, our health survey data contains diagnostic tests, including blood pressure and cholesterol, along with information about specific health-related behaviors such as smoking.

We find that job displacement has a negative effect on health of displaced workers. Importantly, it appears that much of this effect is driven by increases in smoking behavior for both men and women. Interestingly, there is no equivalent health effect on the spouses of these workers. However, we do find some negative health effects on workers in downsizing firms even if they themselves are not displaced. These results are robust to a variety of control groups and specification tests.

The paper unfolds as follows. Section 2 presents the literature review, Section 3 describes the institutional features of Norway during this time period, and Section 4 discusses our empirical strategy. Section 5 describes the data and Section 6 presents results and a variety of robustness and specification checks. Section 7 concludes.

\section{Related Literature}

There is a large literature on the effects of job displacement on earnings. While the consensus is that earnings decline significantly post-displacement, the magnitude varies 
considerably across countries. Researchers have found huge earnings losses for displaced workers in one state in the U.S. in the 1980 s, up to $25 \%$ soon after displacement (Jacobson, LaLonde, Sullivan, 1993), and these results have been confirmed more recently by representative data for the US (Hildreth, von Wachter, and Weber Handwerker, 2012). Earnings losses in Europe have generally been found to be much smaller (from 1-15 percent) but there are often large effects on time out of employment. (See for instance Eliason and Storrie, 2004; Burda and Mertens, 2001; Carneiro and Portugal, 2006; von Wachter and Bender, 2006). In Norway, previous research has found earnings losses from job displacement of only about $5 \%$ (Huttunen, Møen, Salvanes, 2011). ${ }^{2}$

There are also a number of papers on the relationship between general labor market conditions and health. For example, Ruhm $(2000,2005)$ shows that recessions are generally good for health; economic downturns reduce mortality and economic expansions are associated with negative health effects, despite the protective effect of income. Recent work by Asgeirsdottir et al. (2012) uses data from the 2008 economic crisis in Iceland to examine the effect of a macroeconomic shock on health and health behaviors. Overall, their conclusions were ambiguous; they find that the economic crisis was associated with reductions in harmful behaviors such as smoking and heavy drinking. This was combined with a reduction in the consumption of fruits and vegetables and an increase in the consumption of fish oil and improved sleep behavior. While these papers examine the overall health consequences of macroeconomic shocks, we focus on the effects of a specific economic shock to an individual, controlling for general macroeconomic conditions.

\footnotetext{
${ }^{2}$ There is also a relatively small but growing literature on the effect of job displacement on other outcomes. Rege et al (2009) show that job displacement is associated with increased criminal behavior. Page, Oreopoulos and Stevens (2008) find that children of fathers who were displaced earned $9 \%$ less than children of fathers who did not experience a job displacement. Rege, Telle, and Votruba (2011) use data from Norway and find that father's displacement has a negative effect on children's academic performance, while mother's displacement has a positive effect.
} 
There is a much smaller literature focusing on the relationship between job displacement and health outcomes. At the extreme, recent studies have examined how job displacement affects mortality rates. Sullivan and von Wachter (2009) find higher mortality rates for displaced workers in the U.S. in the 1980s (50-100\% higher soon after displacement), with evidence suggesting that these effects are due to the associated decline in income. Equivalent increases in displacement have been found to lead to smaller increases in mortality in Sweden and in Denmark (Eliason and Storrie, 2009b; Browning and Heinesen, 2012). Eliason and Storrie (2009a) use Swedish register data and find that mortality risk among men increased substantially during the first four years (44\%) following job loss, with no effect on female mortality. Browning and Heinesen (2012) use population data from Denmark and also show that mortality increases significantly post-displacement.

However, mortality is a crude indicator of health status; other studies have attempted to look directly at job displacement and health. Unfortunately, these studies have been limited by either small datasets or indirect measures of health status. In the United States, there are several studies of older workers using the Health and Retirement Survey (HRS). Salm (2009) shows that health reasons are common causes of job termination; however, in the case of exogenous job termination, he finds no evidence of effects on various measures of physical and mental health. Because they are using the HRS, the study is limited to older workers and, in the case of exogenous job loss, also faces relatively small sample sizes. Strully (2009) examines the issue using health data from the Panel Study of Income Dynamics (PSID) and finds negative effects of displacement for blue-collar workers but no effects for white-collar workers; again, however, the authors are limited by small sample 
sizes. The general finding in these papers is that displacement is bad for health, but because they observe relatively few displaced workers, they are hampered by low precision. ${ }^{3}$

In contrast, recent European studies have used registry data with large numbers of observations but have been limited by the absence of direct health measures. As a result, they are forced to use more indirect measures of health status. Browning et al. (2006) use a 10\% sample of Danish register data to study stress-related hospitalizations and find no evidence of an adverse effect of displacement. In more recent work, Browning and Heinesen (2012) use data from the Danish population and find that displacement increases certain types of later hospitalizations in Denmark. Rege et al. (2009b) use Norwegian register data to study the effect of displacement on disability pension utilization and find displaced workers were $24 \%$ more likely to have such a pension.

One notable exception is a recent paper by Bergemann, Gronqvist, and Gudbjornsdottir (2011), which uses Swedish data to examine the effect of job displacement on diabetes; they find that incidence of diabetes increases after displacement for single men and for women with small children. Our paper has the advantage of the large sample sizes of registry data combined with actual measures of health and health behaviors such as cholesterol, blood pressure, and smoking.

\section{Institutional Background}

\section{Employment Protection}

Norway is considered to have a relatively high degree of employment protection combined with generous unemployment benefits. When layoffs occur due to a downsizing, there is no legal rule dictating which workers should be laid off. Seniority is a strong norm

\footnotetext{
${ }^{3}$ Marcus (2012) uses German SOEP data to examine the relationship between job loss and health measures; unfortunately, he is also limited by small sample sizes. Bockerman and Ilmakunnas (2009) use data from Finland and show that unemployment does not lead to lower self-assessed health, although there is evidence of selection of unemployment based on health status.
} 
and is institutionalized in agreements, but only where "all else is equal" is the firm supposed to layoff a less senior worker rather than a more senior one. There is one important exception: there are stringent restrictions that limit the capacity of firms to dismiss sick workers.

Most employment contracts require 3 months notice of termination. There is no generalized legal requirement for severance pay; however, workers may be induced to leave voluntarily through severance pay and job search assistance.

\section{Unemployment Insurance}

Unemployment benefits are quite generous in Norway. The benefit is $62.4 \%$ of the previous year's pay, or $62.4 \%$ of the average over the last 3 years, and may be received for up to 3 years. After this period, if still unemployed, a worker may be eligible for means-tested social support. Unemployment benefits are included in our earnings measure, while social support is not. About $78 \%$ of displaced men in our sample are re-employed one year after displacement.

\section{Disability Pension}

Disability benefits are also quite generous in Norway. To receive a disability pension, a person must be a resident in Norway for at least 3 years prior to disability. In order to qualify, it must be the case that "earnings capacity" is permanently reduced by at least $50 \%$ because of illness, injury, or defect. Applicants require a doctor's evaluation of health and loss of earnings capacity. The pension equals some basic amount plus a function of previous earnings. For low-income groups, the replacement rate is high and can be over one and, for most people, it is over 0.5 . As we will see later, disability pensions are not particularly important for our sample. ${ }^{4}$

\footnotetext{
${ }^{4}$ Rege et al. (2009) show that, in Norway, displaced workers are more likely to use disability pensions than other workers. However, this effect should be more relevant to older workers.
} 
Overall, the generous social benefits in Norway are likely to help mitigate the negative effects of displacement. As such, the estimated effects will likely underestimate what the negative health effects of worker displacement would be in a less protective environment.

\section{Empirical Strategy}

Our empirical strategy is a differences-in-differences approach that is motivated by the data available to us. While our employment and earnings data are longitudinal, our health data are cross-sectional in that we only have one observation per person. ${ }^{5}$ Therefore, we cannot compare changes over time in health of individual displaced workers to changes over the same period for the non-displaced. Instead, we compare changes in the conditional mean of health for the displaced and non-displaced groups with the non-displaced operating as a control group for the displaced.

\section{A. Defining Treatment and Control Groups}

The approach in this paper is to compare the post-displacement outcomes of displaced workers to those of other workers who are not displaced. To operationalize this we need the concept of a base year. One can think of the base year as the year in which the displacement event did or did not occur. We follow people for 13 years in total - from 5 years before the base year to 7 years after the base year. So for a given year in our sample, the treatment group is those who were displaced in that year and the control group is those who were not displaced in that year.

Complications arise because people can be displaced more than once in this 13 -year period and so, for example, their outcome in 1990 could be two years after a displacement in

\footnotetext{
${ }^{5}$ There are a few people who appear twice in the health data but not enough to enable us to undertake any longitudinal analysis.
} 
1988 and two years before a subsequent displacement in 1992. To keep things tractable, we (1) only consider the first displacement in the 13 year period for any individual and (2) exclude persons from the control group (the non-displaced) if they experience any displacement in the 13-year period. This implies that we compare post-base year outcomes for persons displaced at the base year but who experienced no prior displacement (in the 13year period) to persons who are not displaced in the same year and who experience no displacement over the 13 -year period. ${ }^{6}$

Because we consider displacements that occur in several different years, in the analysis we redefine each base year as year 0, with the year before displacement being year 1 and the year after being year 1 etc. This enables us to run pooled regressions using all years. In doing so, we always control for the year the displacement (or non-displacement) occurred.

We identify displaced workers using register files from 1986 to 1999. These files include information on all Norwegian residents aged 16-74 in the relevant year. Importantly for us, the files include both a person identifier and a plant identifier so we can identify instances in which a person is working in a particular plant in a particular year but is no longer with that plant the following year. Furthermore, we can identify plant closures from situations in which a plant identifier disappears from the data and measure employment changes at plants by simply counting how many workers are in each plant in each year. We follow the previous literature by defining displaced workers as workers who separate from a plant that closes down or reduces employment by $30 \%$ or more in the year that the separation takes place. (See Jacobsen, Lalonde, and Sullivan, 1993). In addition, we treat workers who leave a plant one year before that plant closes down ("early leavers") as being displaced as they are likely leaving because they are aware of the impending closure.

\footnotetext{
${ }^{6}$ Note that, because of these restrictions, an individual who experiences displacement will appear in only one base year while those in the control group could appear for multiple base years.
} 
The data match workers and plants on May $31^{\text {st }}$ from 1986 until 1995 and on November $20^{\text {th }}$ from 1996 onwards. For displaced workers, year 0 is defined so that they are employed in May (November from 1996) in a certain firm in year 0 but no longer employed in that firm in May (November from 1996) of year 1 (and the period 0 firm has closed down or downsized). This implies that there is uncertainty about the exact timing of displacement. ${ }^{7}$ Because of this, we consider years before the base year as being pre-displacement, years 0 and 1 as enveloping the displacement event, and years 2 to 7 as being post-displacement.

We restrict our sample to individuals with job tenure of at least one year who are working full time (defined as working 30+ hours per week) when last seen at the plant before the displacement event. Additionally, they must have positive earnings for the base year and have had positive earnings in at least one of the previous 5 years (so we can calculate average prior earnings). We exclude plants with fewer than 10 employees in the base year as it is difficult to identify downsizings in very small firms. We use base years that run from 1986 to $1998 .^{8}$

\section{B. Year-by-Year Regressions}

To provide some initial evidence, we regress health in each time period on a dummy variable for whether the person was displaced at time 0 . That is, there are 13 separate regressions going from $t=-5$ to $t=7$. In each period the regression for health is as follows:

$$
H_{i t}=\beta_{0}+\beta_{1} D_{i 0}+X_{i}^{\prime} \delta+\epsilon
$$

Here $D_{i 0}$ is an indicator for whether person $i$ was displaced at time 0 , and $X_{i}$ is a vector of other control variables. Note there is no $t$ subscript on $X_{i}$ because the control variables are

\footnotetext{
${ }^{7}$ Base year 1987 - 1994: Displacement occurred between May of base year and May of the following year. Base year 1995: Displacement occurred between May of base year and November of the following year. Base year 1996 - 1998: Displacement occurred between November of base year and November of the following year.

${ }^{8}$ Although we only have plant information starting in 1986, we have worker income information further back, enabling us to use workers who are displaced starting in 1986.
} 
time invariant. As described in more detail in the next section, our control variables include base year dummies, survey dummies, survey month dummies, age at health measurement, a dummy for whether the person is married in the base year, years of education at the base year, birth order dummies, dummies for number of siblings, a dummy variable for whether the person was born in Norway, month of birth dummies, plant size in the base year (number of employees), a quadratic in tenure in the base year, the average of the log real earnings from $t=-5$ to $t=-1$, dummies for county of residence in the base year, 1-digit industry dummies for the base year industry and, for men, IQ test score at age 18, height at age 18, and a quadratic in BMI at age 18.

Conditional on the controls, the estimate of $\beta_{1}$ gives the difference in average health in each time period between persons displaced at 0 and those not displaced at 0 . If displacement is a random event, we would anticipate seeing no health differences between the treatment and control groups in the five years leading up to displacement. However, displacement is not completely random and anticipation of displacement may lead to some effects appearing even before the displacement actually occurs. To place the health effects in a labor market context, we also show similar regressions where the dependent variables are the log of real earnings and a dummy variable for whether the person is employed.

\section{Difference-in-Differences}

While the year-by-year regressions are informative, they demand a lot from the data. In our further analysis, we increase precision by grouping years together into 4 groups. The groups are periods -5 to $-1(\mathrm{G} 1)$, periods 0 and $1(\mathrm{G} 2)$, periods 2 to $4(\mathrm{G} 3)$, periods 5 to 7

(G4). The first group represents the pre-displacement time period, the second group the "during displacement" time period, and the third group is the immediate post-displacement time period. Finally, group four represents the longer-run post-displacement time period. 
While these groupings are inevitably arbitrary, we consider them to be sensible a priori and we have also verified that there are no significant differences in the displacement effect across time periods within a group.

We estimate the following regression:

$$
H_{i t}=\beta_{0}+\beta_{1} D_{i 0}+\sum_{t=-5}^{6} \mu_{t} I_{i t}+\sum_{g=2}^{4} \varphi_{g} D_{i 0} * g_{i g}+X_{i t}{ }^{\prime} \delta+\epsilon
$$

Here $D_{i 0}$ is an indicator for whether person $i$ was displaced at time $0, I_{i t}$ is an indicator for whether the health report for individual $i$ is at time $t, g_{i g}$ is an indicator for whether the health report for individual $i$ is in time group $g, X_{i t}$ is a vector of other control variables, and $\beta_{0}, \beta_{1}, \mu_{t}, \varphi_{g}$, and $\delta$ are parameter values. Conditional on the controls, the estimate of $\beta_{1}$ gives the pre-displacement difference in health between the displaced and non-displaced. The coefficients of most interest are the $3 \varphi_{g}$ estimates as they give the during- and postdisplacement change in the differences in health between the treatment and control groups (that is, the difference in differences).

\section{Data}

Data are compiled from a number of different sources. Our primary data source is the Norwegian Registry Data, a linked administrative dataset that covers the population of Norwegians up to 2006 and is a collection of different administrative registers such as the education register, family register, and the tax and earnings register. These data are maintained by Statistics Norway and provide information about educational attainment, labor market status, earnings, and a set of demographic variables (age, gender) as well as information on families. ${ }^{9}$ These data are merged to health survey data using personal identification numbers.

\footnotetext{
${ }^{9}$ See Møen, Salvanes and Sørensen (2003) for a description of these data.
} 
The health data come from two population-based surveys carried out between 1988 and 2003 and covering all counties in Norway: the Cohort of Norway (CONOR) and the National Health Screening Service's Age 40 Program. Both surveys were conducted by the National Institute of Public Health, and for the most part, the same information was collected in both surveys. Both consist of two components: the survey and the health examination. The survey part includes questions about specific diseases, general questions about health, medicine use, family disease history, physical activity, and smoking and drinking habits. The health examinations include blood pressure measurement, and blood tests for cholesterol and blood sugar. In addition height, weight, and waist and hip circumference were measured. Finally, there are also questions about education and working conditions.

The main body of data comes from the Age 40 Program, which covers all counties in Norway except Oslo. The Age 40 Program consists of men and women aged 40-42 who were surveyed sometime between $1988-1999 .{ }^{10}$ All 40-42 year olds were asked to participate and the response rate is between 55-80 percent, yielding 374,090 observations. For most counties several cohorts of 40-42 year olds were tested between 1988-1999, and in some cases a wider set of cohorts were tested. ${ }^{11}$

To this, we add the smaller CONOR dataset. The main advantage of the CONOR dataset is that it includes Oslo, which was omitted from the Age 40 data. The smaller CONOR dataset has 56,863 respondents from a wider set of age groups. The response rate is similar to that of the Age 40 Program. ${ }^{12}$

\footnotetext{
${ }^{10}$ The Age 40 Program data set is described http://www.fhi.no and studies such as Jacobsen, Stensvold, Fylkesnes, Kristianen and Thelle (1992), Nystad, Meyer, Nafstad, Tverdal and Engeleand (2004).

${ }^{11}$ Because our health data are collected between 1988 and 1999, workers who were displaced in the earlier part of our sample are unlikely to have health data before displacement while workers displaced in the later part of our sample are unlikely to have post-displacement health observations. This is due to the unbalanced nature of our sample. We have also tried limited our sample to only base years where we observe both pre- and postdisplacement health data and the results are consistent but less precisely estimated.

${ }^{12}$ The CONOR data set is described on the web page www.fhi.no/conor/index.html or in Søgaard (2006), and several studies have used parts or the total sample including Søgaard, Bjelland, Telle and Røysamb (2003).
} 
For approximately $26 \%$ of observations, we have registry data but are missing health data for cases that were within the sample frames for the health surveys. Not surprisingly, this nonresponse is not purely random but is correlated with individual characteristics. Among men, responders have slightly lower education (11.1 versus 11.5 years), are slightly more likely to be married (.79 versus .78), have slightly higher tenure (7.7 versus 7.6$)$, have slightly lower wages at time -1 (7.46 versus 7.54$)$, and are slightly less likely to be displaced at some point (.31 versus .33$)$. These numbers suggest that, although there are statistically significant differences, they are sufficiently small that they are unlikely to lead to large biases in estimation. ${ }^{13}$

\section{A. Health Outcomes}

Unfortunately, not all variables are available in all surveys so we concentrate on a set of health outcomes that are always present and are particularly related to heart health. Our main health variable is an indicator for coronary heart disease and stroke based on the Framingham risk model. ${ }^{14}$ This index includes current smoking behavior, blood pressure, cholesterol level, age and gender (See Anderson, Wilson, Odell and Kannel, 1991; Bjartveit, 1986). ${ }^{15}$ The measure for blood pressure is systolic blood pressure, for cholesterol it is serum concentration in mmol/1, and for smoking is the number of cigarettes smoked daily. In addition to this index, we also look at the separate effects of displacement on cholesterol, blood pressure, BMI, and whether an individual smokes. ${ }^{16}$

\section{B. Control Variables}

\footnotetext{
${ }^{13}$ Previous studies have found little indication of self-selection on observable family background variables in CONOR when compared to the whole population (Søgaard, Selmer, Bjertnes, Thelle, 2003).

${ }^{14}$ See the appendix for a description of the Framingham index and how exactly we calculate it.

${ }^{15}$ In 1988, it became illegal to smoke in public areas such as offices in factories in Norway. In 1993, this was extended to include restaurants.

${ }^{16}$ We also examined the effect of displacement on the number of cigarettes smoked but found no evidence of any effect on the intensity of smoking behavior.
} 
Since job displacement is not random, we control for a large set of variables in our regressions. We include controls for age at health measurement, survey dummies, and survey month dummies obtained from the health surveys. We also use variables that are created from other register files. These include a dummy for whether the person is married in the base year, years of education at the base year, birth order dummies, dummies for number of siblings, a dummy variable for whether the person was born in Norway, month of birth dummies, plant size in the base year (number of employees), dummies for county of residence in the base year, and 1-digit industry dummies for the base year industry. The register data include job start dates and we use these to calculate tenure of the worker at the plant.

We also control for the average of the log real earnings from $t=-5$ to $t=-1$. Earnings are measured as total pension-qualifying earnings reported in the tax registry and are available on a calendar year basis. These are not top-coded and include labor earnings, taxable sick benefits, unemployment benefits, parental leave payments, and pensions. Earnings are available from 1967 onwards and so we are able to calculate average log earnings in the 5 years preceding displacement i.e. for persons displaced in 1986, we calculate average log earnings between 1981 and 1985. In situations where earnings are missing or zero in any particular year, we simply take the average of earnings over those years in which the person had positive earnings. Earnings are deflated using the Consumer Price Index with base year 1998.

For men, we also control for IQ test score, height, and a quadratic function of body mass index (BMI). All are measured predominantly between the ages of 18 and 20. These variables are taken from the Norwegian military records from 1980 to 2005. In Norway, military 
service is compulsory for every able young man; as a result, we have military data for men only. ${ }^{17}$

The IQ measure is the mean score from three IQ tests -- arithmetic, word similarities, and figures (see Sundet et al. [2004, 2005] and Thrane [1977] for details). The arithmetic test is quite similar to the arithmetic test in the Wechsler Adult Intelligence Scale (WAIS) [Sundet et al. 2005; Cronbach 1964], the word test is similar to the vocabulary test in WAIS, and the figures test is similar to the Raven Progressive Matrix test [Cronbach 1964]. The IQ score is reported in stanine (Standard Nine) units, a method of standardizing raw scores into a nine point standard scale that has a discrete approximation to a normal distribution, a mean of 5 , and a standard deviation of $2 .{ }^{18}$ We have IQ scores for approximately $90 \%$ of the relevant population of men in Norway.

\section{Empirical Results}

\section{A. Differences between the Treatment and Control Group}

In Table 1 we report the time 0 differences between the characteristics of the control and treatment groups. We also report the p-value for the null hypothesis that the means are equal in the two groups. As is generally found in displacement studies, there are some systematic differences between the two groups. While age, family background variables (family size, birth order), and marital status are not significantly different for the two groups, displaced workers have lower education, lower job tenure, and have experienced more unemployment prior to displacement. Earnings prior to displacement are not significantly

\footnotetext{
${ }^{17}$ Norway has mandatory military service of between 12 and 15 months (fifteen in the Navy and twelve in the Army and Air Force) for men between the ages of 18.5 (17 with parental consent) and 44 (55 in case of war). However, the actual draft time varies between six months and a year, with the rest being made up by short annual exercises.

${ }^{18}$ The correlation between this IQ measure and the WAIS IQ has been found to be .73 (Sundet et al., 2004).
} 
different between the two groups for men but lagged earnings are lower for displaced women than for other women.

\section{B. Year-by-Year Regressions}

The estimates from the year-by-year regressions for health outcomes are in Table 2. Appendix Table 1 presents the equivalent estimates for log earnings and employment status, shown to provide some context. Earnings losses for men are about $6 \%$ one year after displacement and then slowly fall to about 3\% after seven years; while this earnings effect is small compared to previous estimates from the U.S., it is consistent with prior findings from Norway (Huttunen, Møen and Salvanes, 2011). For women, the earnings effects are similar in magnitude but appear to persist much longer. The results for whether employed show that there are small differences in employment experiences even before displacement. By construction, all sample members are employed in the year of displacement but the displaced are less likely to be employed a few years before that. However, the effects of displacement are obvious as, at $\mathrm{t}=1$, the effect of displacement on employment probability peaks at about $18 \%$ for both men and women. This falls to about $11 \%$ for men ( $13 \%$ for women) in year 2 and is smaller again in subsequent years. Once again, these effects are similar in magnitude to those reported by Huttunen, Møen and Salvanes (2011).

The health estimates in Table 2 show that, conditional on the control variables, predisplacement health (health between $t=-5$ to $t=-1$ ) is not significantly different between the treatment and control group. This is true for cholesterol, blood pressure, smoking (whether smoke daily), and the Framingham index. Also, it is true for both men and women.

For men, there is little evidence that displacement has any effect on cholesterol and blood pressure, as the effects are small and statistically insignificant in almost all postdisplacement periods. There is some evidence that displacement leads to higher cholesterol 
for women. The standard deviation of the cholesterol measure is about 1 for women in our sample, so the estimates indicate that displacement may increase cholesterol by about one twentieth of a standard deviation. This is a small effect that appears soon after displacement and seems to persist until $\mathrm{t}=4$. There is no evidence of any adverse effect of displacement on blood pressure for women; indeed, we find a negative effect on blood pressure 7 years after displacement.

Despite the absence of obvious effects of displacement on health, there are clear effects on the proportion that smoke daily. Among men, the proportion of the treatment group smoking daily increases relative to the control group during the displacement period $(\mathrm{t}$ $=0$ and $\mathrm{t}=1)$ and the differences remain for the full period after displacement. It appears that displacement may lead to a permanent increase in daily smoking probability of about .02 for men. ${ }^{19}$ This translates into an increase in the Framingham index after displacement. The results for women suggest a similar increase in daily smoking probability due to displacement. However, there is no evidence that the effects persist for longer than 4 years. As with men, the effects of displacement on the Framingham index are dominated by smoking, and the estimates for this index display the same temporal pattern as do the smoking estimates. The magnitudes of the Framingham index estimates (.1 to .2) suggests a small effect as the standard deviation is about 5 .

\section{Difference-in-Differences Estimates}

Table 3 contains the means of each of the four health outcome variables by displacement status both before and after displacement. For women, we see that cholesterol is the same on average for both groups pre-displacement but then it rises slightly for the displaced but not for the non-displaced. Displaced women were slightly more likely to smoke

\footnotetext{
${ }^{19}$ The smoking estimates come from linear probability model. We have verified that the marginal effects and associated standard errors from a probit model are almost identical.
} 
pre-displacement; then smoking probability falls for the non-displaced but increases for the displaced. This table is suggestive; however, since these are just raw means, the numbers could be influenced by compositional shifts.

The regression-based difference-in-differences estimates are in Table 4. In addition to the four health variables considered earlier, we add estimates here for sickness benefit, disability benefit, body mass index, and an alternative heart risk index (the Westerlund risk of cardiovascular disease) that is a relative rather than an absolute index (see the appendix for details). The estimates are consistent with the year-by-year regression results: among men, there is very little evidence of a negative effect of displacement on any of the health measures other than smoking, and as before, the smoking effect persists over time. Among women, we also find an effect on smoking. In addition, there is evidence that displacement leads to higher cholesterol; there is little evidence of any effect on any of the other indicators. ${ }^{20}$

\section{Robustness Checks}

We next report the findings from a variety of different robustness checks. For brevity, we only report estimates for the Framingham index as the dependent variable. However, results using other outcomes were also robust to these checks.

\section{Effect by Type of Displacement Event}

While a job displacement is a very specific event, we next look at whether the underlying cause of the displacement affects the magnitude of our findings, as it is quite

\footnotetext{
${ }^{20}$ Appendix Table 2 lists the coefficient estimates for the control variables for the regression in which the Framingham index is the dependent variable (Table 4). One interesting coefficient is that on pre-displacement earnings. Ignoring the endogeneity of earnings, the coefficient of -.135 for men implies that a 10\% increase in average earnings reduces heart risk by just over 0.001 of a point. Displacement reduced earnings of men by about $6 \%$ in time periods $2-4$ and this would then imply an earnings effect on heart risk that is quite tiny. The coefficient on earnings in the female regression is small and statistically insignificant. If the OLS effect of earnings is reasonable, it suggests that earnings losses are not an important channel in the decrease in health from displacement for either men or women.
} 
likely that the exact nature of a displacement event matters for health. These estimates are in Table 5. One distinction we make is between those individuals who lose jobs due to a downsizing and those who lose jobs because their plant closes. When we split the sample into these two groups, it is clearly the case that the negative effects of a plant closure dominate that of a downsizing with the differences being particularly large for women.

Some workers are displaced but transfer to another plant in the same firm (there are 4191 of these cases for men, 1320 for women). One might expect that these workers have a much less stressful experience than other displaced workers so we report estimates in Table 5 where they are omitted from the sample. As expected, the effects of displacement are larger here than in Table 3 for both men and women and now are statistically significant for men in each of the 3 post-displacement periods.

Finally, to select a group that may be particularly adversely affected, we restrict the treatment group to persons whose plant closed and who did not move to another plant in the same firm (keeping the control group the same). The estimates are in the last row of Table 5. We now see strong evidence of health impacts for both men and women and they appear to persist for years after displacement. The magnitudes here are also significant at about a third of a standard deviation for men and close to a full standard deviation effect for women.

\section{Alternative Control Groups}

Our baseline control group includes all individuals who are not displaced over the benchmark 13-year period. As such, it includes individuals who are in firms that are downsized but who are not themselves displaced. It is reasonable to believe, however, that being in a plant that experienced a large downsizing may increase workloads and stress levels for those who remain, thus having negative impacts on measured health. Therefore, we report estimates where this group is excluded from the analysis (Control Group 2). 
Those who are separated from their jobs but not a part of a mass displacement are also included in the baseline control groups. One might be concerned that these individuals are very different from those who are displaced and, as such, not appropriate for the control group. As a robustness check, we also report estimates in which these people are omitted from the sample (Control Group 3). ${ }^{21}$

The results with these alternative control groups are presented in Appendix Table 3. Importantly, the estimates change very little when stayers from downsizing firms are excluded from the control group (Control Group 2) but the displacement effects increase when non-displaced separators are excluded from the control group. Overall, the estimates appear quite robust to the choice of control group.

\section{Using the Propensity Score}

As is typically the case in displacement studies, we saw that there are systematic differences between some characteristics of the treatment and control groups (Table 1). An alternative to the regression approach is to use propensity score matching. We implement two variants of this in conjunction with the regression analysis. ${ }^{22}$ First, we use the estimated propensity score to reweight observations so that the weighted probability of displacement is the same in both the treatment and control groups. We then report regression estimates using these weights. Second, as suggested by Angrist and Pischke (2009), we use the estimated propensity score as a pre-screen in the regression analysis. Intuitively, we exclude observations with outlier values of the propensity score and check the robustness of our regression estimates to this exclusion. Note that a limitation of the propensity score approach is that we do not know pre-displacement health for persons whose health is measured postdisplacement. Therefore, we cannot use health information in forming the propensity score.

\footnotetext{
${ }^{21}$ While separators are excluded, Control Group 3 includes persons from downsizing firms who are not displaced.

${ }^{22}$ We revert to our original treatment and control groups for the propensity score analysis.
} 
Because displacement is a fairly random event, even our rich set of control variables have little explanatory power for whether a person is displaced at base year. For men, the pseudo $\mathrm{R}^{2}$ from a logit regression is only $0.03 .{ }^{23}$ Education has a statistically significant but small negative effect in that an extra year of education reduces the probability of displacement by 0.002 . Being a native Norwegian reduces the probability of displacement by 0.02 , and an extra centimeter of height at age 18 reduces the probability of displacement by a statistically significant but tiny .0006 . Surprisingly, there is a small positive relationship between cognitive test scores at age 18 and displacement. Displacements are more likely in bigger plants and there is the expected quadratic relationship between tenure and displacement probability. There is no evidence of any relationship between BMI, lagged average earnings, 1-digit industry, month of birth, family size, birth order, marital status, or age on displacement probability for men. The results for women are generally similar.

Panel 3 of Appendix Table 2 shows regression estimates where observations have been weighted using the estimated propensity score. Panels 4 and 5 show unweighted estimates where the propensity score has been used to pre-screen observations; observations with extreme values of the score have been omitted from the regression. ${ }^{24}$ Both of these methods give estimates that are similar to the baseline difference-in-differences estimates from Table 4.

\section{Heterogeneous Effects}

It is possible that income, age, or marital status may mitigate the effects of job displacement in terms of health. In Appendix Table 4, we report estimates from specifications that allow for heterogeneous effects by tenure, education, firm size, and marital

\footnotetext{
${ }^{23}$ This logit regression included the same set of controls that we use in the main analysis.

${ }^{24}$ One pre-screen omits observations where the propensity score is outside the $(.02-.15)$ range; the other restricts the range to $(.03-.10)$. The latter reduces the sample size by over a fifth.
} 
status. Interestingly, there is no strong evidence for differences by group; while some of the point estimates differ, the differences are small relative to the standard errors. ${ }^{25}$

As another check, we have tested whether the size of the health effects of displacement vary with the county unemployment rate. One might expect that people displaced when unemployment is very high will suffer more as a result. However, we have found no evidence for this. When we restrict the sample to base years and counties where the unemployment rate is at least $4 \%$ (less than $1 / 3$ of the sample) we find quite similar estimates to those from the full sample. This may be because unemployment rates are generally low over this period, with the average unemployment rate being about $3 \%$.

\section{E. Intent-to-treat Estimates}

One concern with the previous estimates is that, when a plant is downsizing, it may systematically choose to lay off the least healthy employees, as they are also likely to be less productive. ${ }^{26}$ Additionally, firms sometimes seek voluntary layoffs when downsizing and persons who volunteer to be displaced may be less healthy. The similarity of health before the base year of displaced and non-displaced workers suggests that this is not a big issue but does not rule it out altogether.

We follow the previous literature in addressing this point by including non-displaced employees from downsizing firms in the treatment group (Sullivan and von Wachter, 2009). In effect, this defines the treatment at the firm level. Note that, in addition to the possible selection issue described above, it is possible that our estimates change because displacement has a negative (or positive) effect on stayers in downsizing firms. A negative effect could arise if the employment reduction increased the workload and stress of remaining employees,

\footnotetext{
${ }^{25} \mathrm{We}$ also allowed for heterogeneous effects by the baseline employment status of the spouse and find no evidence of differential effects.

${ }^{26}$ This would be despite the fact that it is illegal to lay off workers based on their health status.
} 
a positive effect could arise if the displacement reduced uncertainty and made remaining workers confident that the firm would now be viable and their jobs remain safe. Sullivan and von Wachter (2009) refer to estimates using the firm-level definition of displacement as “intent-to-treat” estimates.

The "intent-to-treat" estimates are in Table 6. If non-displaced workers are unaffected by downsizings, we would expect estimates to be a bit smaller than earlier as the treatment group now contains both affected and unaffected people. However, in general, the estimates are quite similar to the estimates where only displaced workers are included in the treatment group, suggesting that workers in affected firms may also bear the cost of the firm downsizing, even if they themselves are not displaced. We have looked at this question directly by comparing the outcomes of non-displaced persons in downsizing firms to those who are not displaced and are not in downsizing firms. Interestingly, we find that there is an increase in smoking probability of about .05 at the time of downsizing but the effect disappears after $\mathrm{t}=1$. There are indications that the health of persons in downsizing firms actually improves in the longer term as cholesterol and the heart risk index actually fall after $\mathrm{t}=1$. These estimates are consistent with the immediate effects of a displacement event being stressful for all employees but the longer term health effects on the "survivors" being positive. For women, there is no evidence of any health effects of downsizing on the nondisplaced population.

\section{F. Cross-Effects}

Finally, we have also examined whether displacement has any effect on the health of spouses. Perhaps unsurprisingly given the small health effects on the individual who is 
directly affected, we have found no evidence that the health of spouses is affected in the short-run. ${ }^{27}$ This is true when either the male or the female is the displaced worker.

\section{Conclusion}

Firm expansion and contraction are key elements to a well-functioning economy. However, the process is not costless. Much of the recent research has focused on the financial costs that are faced by workers, demonstrating the significant and potentially longlasting effects of job displacement. However, much less is known about the health effects of these types of labor market shocks.

Using rich, detailed health data from Norway matched to administrative register data, we show that job displacement has a significant effect on cardiovascular health around age 40. Importantly, this is almost entirely explained by changes in individual health behaviors; smoking increasing significantly for both men and women immediately after displacement. Interestingly, there is no equivalent short-run health effect on the spouses of these workers.

In general the effects we find are quite small; however, as one might expect, the health consequences of displacement are larger for those hardest hit--the subset of workers whoso plants close and whose next job is not in another plant in the same firm. Among these workers, we find substantial negative health effects for both men and women. In addition, individuals from firms who downsize but who are not themselves laid off also experience a negative health shock; however, this shock appears short-lived and there is some evidence that they may actually have better health in the longer run.

\footnotetext{
${ }^{27}$ There may be longer run effects, for example due to exposure to second-hand smoke.
} 


\section{References}

Anderson, K. M., P. M. Odell, P. W. Wilson, and W. B. Kannel. 1991. "Cardiovascular Disease Risk Profiles." Am Heart J., 121(1 Pt 2):293-8.

Angrist, Joshua D., and Jörn-Steffen Pischke. 2009. Mostly Harmless Econometrics: An Empiricists Companion. Princeton: Princeton University Press.

Asgeirsdottir, Tinna Laufey, Hope Corman, Kelly Noonan, Torhildur Olafsdottir, Nancy E. Reichman. 2012. "Are Recessions Good for Your Health Behaviors? Impacts of the Economic Crisis in Iceland.” NBER Working Paper \#18233.

Bergemann, Annette, Erik Gronqvist, and Soffia Gudbjornsdottir, 2011. "The Effects of Job Displacement on the Onset and Progression of Diabetes." Netspar discussion paper 03/2011.

Bjartveit K. 1986. "Effect of intervention on coronary heart disease risk factors in some Norwegian counties." Am J Med, 80(2A):12-7.

Bockerman, Petri and Pekka Ilmakunnas, 2009. "Employment and Self-Assessed Health: Evidence from Panel Data." Health Economics V. 18: 161-179.

Bosma, H., Peter, R., Siegrist, J., and M. Marmot. 1998. "Two Alternative Job Stress Models and the Risk of Coronary Heart Disease." American Journal of Public Health, 88: 68-74.

Browning, Martin, Anne Danø Møller, and Eskil Heinesen. 2006. "Job displacement and stressrelated health outcomes." Health Economics, 15: 1061-1075.

Browning, Martin and Eskil Heinesen (2012). "The effect of job loss due to plant closure on mortality and hospitalization." Journal of Health Economics, 31: 599-616.

Burda, Michael C., and Antje Mertens. 2001. "Estimating wage losses of displaced workers in Germany." Labour Economics, 8, 15-41.

Carneiro, Anabela, and Pedro Portugal. 2006. "Earnings Losses of Displaced Workers: Evidence from a Matched Employer-employee Data Set.” CETE Discussion Paper No. 0607.

Cronbach, Lee J. 1964. Essentials of Psychological Testing, 2nd Edition. London, UK: Harper and Row.

Eliason, Marcus and Donald Storrie. 2004. "The Echo of Job Displacement." ISER Working Paper 2004-20, Institute for Social and Economic Research.

Eliason, Marcus and Donald Storrie. 2009a. "Job Loss is Bad for your Health - Swedish Evidence on Cause-Specific Hospitalization following Involuntary Job Loss.” Social Science and Medicine, 68: 1396-1406.

Eliason, Marcus and Donald Storrie. 2009b. “Does Job Loss shorten Life?” Journal of Human Resources, 44(2): 277-302.

Falba, T., H. M. Teng, J. L. Sindelar, and W. T. Gallo. 2005. “The Effect of Involuntary Job Loss on Smoking Intensity and Relapse." Addiction 100(9):1330-9. 
Farber, Hank S. 2005. "What Do We Know About Job Loss in the U.S.? Evidence from the Displaced Workers Survey, 1984-2004.” Economic Perspectives. 2005;2Q:13-28.

Gallo, William T., Elizabeth H. Bradley, and Stanislav V. Kasl. 2001. "The effect of job displacement on subsequent health." Quarterly Journal of Economic Research, 70:159-65.

Gallo, William T. Elizabeth H. Bradley, Tracy A. Falba, Joel A. Dubin, Laura D. Cramer, Sidney T. Bogardus Jr., and Stanislav V. Kasl. 2004. "Involuntary Job Loss as a Risk Factor for Subsequent Myocardial Infarction and Stroke: Findings from the Health and Retirement Survey." American Journal of Industrial Medicine, 45:408-416.

Hildreth, Andrew K. G., Till von Wachter, and Weber Handverker. 2008. "Estimating the 'True' Cost of Job Loss: Evidence Using Matched Data from California 1991-2000." Memo, Columbia University.

Huttunen, Kristiina, Jarle Møen, and Kjell G. Salvanes. 2011. "How Destructive is Creative Destruction? Effects of Job Loss on Job Mobility, Withdrawal, and Income" Journal of the European Economic Association. 9 (5): 840 - 870.

Jacobson, Louis S, Robert J. LaLonde, Daniel Sullivan. 1993. "Earnings Losses of Displaced Workers.” American Economic Review, 83:685-709.

Jacobsen B.K., I. Stensvold, K. Fylkesnes, I. S. Kristiansen, G. S. Thelle. 1992. "The Nordland health study", Scandinavian Journal of Social Medicine, 20 (3): 184-7.

Kivimäki, M., Leino-Arjas, P., Luukkonen, R., Riihimäki, H., Vahtera, J. and Kirjonen, J. 2002. "Work Stress and Risk of Cardiovascular Mortality: Prospective Cohort Study of Industrial Employees.” British Medical Journal, 325:857-861.

Kuhn, Andreas, Rafael Lalive, and Josef Zweimfiller. 2007. "The Public Health Costs of Unemployment," Cahiers de Recherches Economiques du Departement d'Econometrie et d'Economie politique07.08, University de Lausanne, Faculte des HEC.

Marcus, Jan. 2012. “Does Job Loss Make You Smoke and Gain Weight?” mimeo, January.

Martikainen, Pekka, Netta Maki, and Markus Jantti. 2007."The Effects of Unemployment on Mortality Following Workplace Downsizing and Workplace Closure: A Register-Based Follow-Up Study of Finnish Men and Women during Economic Boom and Recession," American Journal of Epidemiology, 165:1070-1075.

Morris, JK, D.G Cook. 1991. "A critical review of the effect of factory closures on health." $B r J$ Ind Med, 48: 1-8.

Møen, Jarle, Kjell G. Salvanes and Erik Ø. Sørensen. 2003. "Documentation of the Linked Empoyer Employee Data Base at the Norwegian School of Economics," Mimeo, The Norwegian School of Economics and Business Administration. 
Nystad W., H.E. Meyer, P. Nafstad, A.Tverdal, A. Engeland. 2004. "Body mass index in relation to adult asthma among 135,000 Norwegian men and women." American Journal of Epidemiology, 160(10):969-76.

Page, Marianne, Phil Oreopoulos, and Ann Stevens. 2008. "The Intergenerational Effects of Worker Displacement." Journal of Labor Economics, 26(3):455-484.

Rege, Mari, Torbjrøn Skardhamar, Kjetil Telle, Mark Votruba. 2009a. "Job Loss and Crime.” Discussion Paper No. 593, Research Department, Statistics Norway.

Rege, Mari, Kjetil Telle, and Mark Votruba. 2009b. "The Effect of Plant Downsizing on Disability Pension Utilization." Journal of the European Economic Association, 7(4):754-785.

Rege, Mari, Kjetil Telle, Mark Votruba.2011. "Parental Job Loss and Children's School Performance." Review of Economic Studies, 78: 1462-1489.

Ruhm Christopher. 2000. “Are recessions good for your health?” Quarterly Journal of Economics, 115(2): 617-650.

Ruhm, Christopher. 2005. "Healthy Living in Hard Times." Journal of Health Economics, 24(2):341-63.

Salm, Martin. 2009. “Does Job Loss Cause Ill Health?” Health Economics, 18(9), 1075-1089.

Sullivan, Daniel and Till von Wachter. 2009. "Job Displacement and Mortality: An Analysis Using Administrative Data." Quarterly Journal of Economics, 124 (3): 1265-1306.

Strully, Kate W. 2009. "Job Loss and Health in the U.S. Labor Market.” Demography, 46(2): 221246.

Sundet, Martin Jon, Dag G. Barlaug, and Tore M. Torjussen. 2004. "The End of the Flynn Effect? A Study of Secular Trends in Mean Intelligence Test Scores of Norwegian Conscripts During Half a Century." Intelligence, XXXII: 349-362.

Sundet, Jon Martin, Kristian Tambs, Jennifer R. Harris, Per Magnus, and Tore M. Torjussen.2005.“ Resolving the Genetic and Environmental Sources of the Correlation Between Height and Intelligence: A Study of Nearly 2600 Norwegian Male Twin Pairs." Twin Research and Human Genetics, VII: 1-5.

Søgaard, A. J. 2006. "Cohort Norway (CONOR). Materials and methods." memo, Norwegian Institute of Public Health.

Søgaard, A. J., R. Selmer, E. Bjertnes, G. D. Thelle. 2003. "The Oslo Health Study. The impact of Self-selection in a Large, Populations-based Survey." 2003. International Journal of Equity in Health, 3(3): 3-13.

Søgaard, A. J., I. Bjelland, G. S. Thelle, and E. Røysamb. 2003. "A comparison of the CONOR Mental Health Index to the HSCL-10 and HADS Measuring mental health status in The Oslo Health Study and the Nord-Trøndelag Health Study.” Norsk Epidemiologi, 13(2): 279-284. 
Thrane, Vidkunn Coucheron. 1977. "Evneprøving av Utskrivingspliktige i Norge 1950-53," Arbeidsrapport nr. 26, INAS.

Von Wachter, Till, and Stefan Bender. 2006. "In the Right Place at the Wrong Time: The Role of Firms and Luck in Young Workers' Careers." American Economic Review, 96(5): 16791705. 
Table 1: Means by Displacement Status (At time 0) MEN

\begin{tabular}{|c|c|c|c|}
\hline Variable & Displaced & Not Displaced & $\begin{array}{l}\text { P value for } \\
\text { difference }\end{array}$ \\
\hline Age & $\begin{array}{l}41.31 \\
(0.04)\end{array}$ & $\begin{array}{l}41.26 \\
(0.01)\end{array}$ & 0.34 \\
\hline Education & $\begin{array}{l}11.10 \\
(0.05)\end{array}$ & $\begin{array}{l}11.27 \\
(0.01)\end{array}$ & $<0.01$ \\
\hline IQ Score & $\begin{array}{c}5.89 \\
(0.05)\end{array}$ & $\begin{array}{c}5.82 \\
(0.01)\end{array}$ & 0.11 \\
\hline Tenure & $\begin{array}{c}7.23 \\
(0.09)\end{array}$ & $\begin{array}{c}8.64 \\
(0.02)\end{array}$ & $<0.01$ \\
\hline Height (at 18) & $\begin{array}{l}178.57 \\
(0.16)\end{array}$ & $\begin{array}{l}178.93 \\
(0.04)\end{array}$ & 0.02 \\
\hline BMI (at 18) & $\begin{array}{l}21.32 \\
(0.06)\end{array}$ & $\begin{array}{l}21.51 \\
(0.01)\end{array}$ & $<0.01$ \\
\hline Lagged Earnings & $\begin{array}{c}12.51 \\
(0.006)\end{array}$ & $\begin{array}{c}12.52 \\
(0.002)\end{array}$ & 0.25 \\
\hline Plant Size at 0 & $\begin{array}{c}265.02 \\
(7.74)\end{array}$ & $\begin{array}{c}245.32 \\
(2.05)\end{array}$ & 0.02 \\
\hline Family Size & $\begin{array}{c}2.91 \\
(0.03)\end{array}$ & $\begin{array}{c}2.92 \\
(0.01)\end{array}$ & 0.84 \\
\hline Birth Order & $\begin{array}{c}1.70 \\
(0.02)\end{array}$ & $\begin{array}{c}1.71 \\
(0.005)\end{array}$ & 0.55 \\
\hline Native & $\begin{array}{c}0.96 \\
(0.004)\end{array}$ & $\begin{array}{c}0.97 \\
(0.001)\end{array}$ & $<0.01$ \\
\hline Married & $\begin{array}{c}0.77 \\
(0.01)\end{array}$ & $\begin{array}{c}0.77 \\
(0.002)\end{array}$ & 0.86 \\
\hline Months Unemployed at -1 & $\begin{array}{c}0.08 \\
(0.01)\end{array}$ & $\begin{array}{c}0.04 \\
(0.002)\end{array}$ & $<0.01$ \\
\hline Number of Observations & 3019 & 46455 & \\
\hline
\end{tabular}


Table 1: Means by Displacement Status (At time 0)

WOMEN

\begin{tabular}{|c|c|c|c|}
\hline Variable & Displaced & Not Displaced & $\begin{array}{l}\mathrm{P} \text { value for } \\
\text { difference }\end{array}$ \\
\hline Age & $\begin{array}{l}41.17 \\
(0.09)\end{array}$ & $\begin{array}{l}41.26 \\
(0.02)\end{array}$ & 0.34 \\
\hline Education & $\begin{array}{l}10.43 \\
(0.07)\end{array}$ & $\begin{array}{l}10.61 \\
(0.02)\end{array}$ & $<0.01$ \\
\hline Tenure & $\begin{array}{c}6.13 \\
(0.15)\end{array}$ & $\begin{array}{c}7.15 \\
(0.04)\end{array}$ & $<0.01$ \\
\hline Lagged Earnings & $\begin{array}{l}12.08 \\
(0.01)\end{array}$ & $\begin{array}{c}12.15 \\
(0.003)\end{array}$ & $<0.01$ \\
\hline Plant Size at 0 & $\begin{array}{l}183.62 \\
(10.41)\end{array}$ & $\begin{array}{l}204.45 \\
(3.53)\end{array}$ & 0.14 \\
\hline Family Size & $\begin{array}{c}2.97 \\
(0.05)\end{array}$ & $\begin{array}{c}2.97 \\
(0.01)\end{array}$ & 0.87 \\
\hline Birth Order & $\begin{array}{c}1.78 \\
(0.04)\end{array}$ & $\begin{array}{c}1.75 \\
(0.01)\end{array}$ & 0.46 \\
\hline Native & $\begin{array}{c}0.97 \\
(0.005)\end{array}$ & $\begin{array}{c}0.97 \\
(0.001)\end{array}$ & 0.95 \\
\hline Married & $\begin{array}{c}0.67 \\
(0.01)\end{array}$ & $\begin{array}{c}0.67 \\
(0.004)\end{array}$ & 0.81 \\
\hline Months Unemployed at -1 & $\begin{array}{c}0.10 \\
(0.01)\end{array}$ & $\begin{array}{c}0.04 \\
(0.003)\end{array}$ & $<0.01$ \\
\hline Number of Observations & 1047 & 15773 & \\
\hline
\end{tabular}


Table 2A: Effect of Displacement on Outcomes (Men)

\begin{tabular}{|c|c|c|c|c|}
\hline Time & Cholesterol & Blood Pressure & Smoking & Framingham Index \\
\hline \multirow[t]{3}{*}{-5} & .033 & -.223 & -.001 & .035 \\
\hline & $(.035)$ & $(.435)$ & $(.016)$ & $(.100)$ \\
\hline & [24931] & [25130] & [25163] & [24927] \\
\hline \multirow[t]{3}{*}{-4} & $-.064 * *$ & .166 & .001 & -.084 \\
\hline & $(.031)$ & $(.385)$ & $(.014)$ & $(.088)$ \\
\hline & [29060] & [29246] & [29299] & [29056] \\
\hline \multirow[t]{3}{*}{-3} & .005 & -.315 & .003 & 0.002 \\
\hline & $(.026)$ & $(.297)$ & $(.011)$ & $(.073)$ \\
\hline & [34258] & [34425] & [34497] & [34238] \\
\hline \multirow[t]{3}{*}{-2} & .017 & -.056 & .014 & .074 \\
\hline & $(.025)$ & $(.290)$ & $(.011)$ & $(.069)$ \\
\hline & [39256] & [39413] & [39488] & [39219] \\
\hline \multirow[t]{3}{*}{-1} & .019 & .084 & .013 & 0.101 \\
\hline & $(.023)$ & $(.282)$ & $(.010)$ & $(.066)$ \\
\hline & [43196] & [43337] & [43403] & [43135] \\
\hline \multirow[t]{3}{*}{0} & .011 & .343 & $.017 * *$ & $.129 * *$ \\
\hline & $(.020)$ & $(.259)$ & $(.009)$ & $(.059)$ \\
\hline & [49185] & [49341] & [49352] & [49063] \\
\hline \multirow[t]{3}{*}{1} & .013 & .062 & $.023 * *$ & $.121 * *$ \\
\hline & $(.019)$ & $(.235)$ & $(.008)$ & $(.055)$ \\
\hline & [54304] & {$[54473]$} & [54364] & [54053] \\
\hline \multirow[t]{3}{*}{2} & .003 & .115 & $.021 * *$ & $.109 * *$ \\
\hline & $(.018)$ & $(.233)$ & $(.008)$ & $(.054)$ \\
\hline & [55103] & [55256] & [55181] & [54874] \\
\hline \multirow[t]{3}{*}{3} & $.044 * *$ & .102 & $.038 * *$ & $.242 * *$ \\
\hline & $(.019)$ & $(.221)$ & $(.008)$ & $(.052)$ \\
\hline & [53670] & [55825] & [53734] & [53427] \\
\hline \multirow[t]{3}{*}{4} & .029 & -.147 & $.023 * *$ & $.136^{* *}$ \\
\hline & $(.018)$ & $(.215)$ & $(.008)$ & $(.052)$ \\
\hline & [49184] & [49203] & [49116] & [48949] \\
\hline \multirow[t]{3}{*}{5} & .004 & -.296 & $.040 * *$ & $.209 * *$ \\
\hline & $(.019)$ & $(.233)$ & $(.009)$ & $(.056)$ \\
\hline & [44851] & [44826] & [44725] & [44610] \\
\hline \multirow[t]{3}{*}{6} & -.005 & .107 & .007 & -.009 \\
\hline & $(.020)$ & $(.241)$ & $(.009)$ & $(.056)$ \\
\hline & [40248] & [40220] & [40099] & [40011] \\
\hline \multirow[t]{3}{*}{7} & -.003 & .227 & $.026 * *$ & $.135^{* *}$ \\
\hline & $(.020)$ & $(.258)$ & $(.009)$ & $(.060)$ \\
\hline & [34515] & [34488] & [34366] & [34285] \\
\hline
\end{tabular}

All coefficients come from separate regressions with the full set of control variables. The control variables include base year dummies, survey dummies, survey month dummies, age at health measurement, a dummy for whether the person is married in the base year, years of education at the base year, birth order dummies, dummies for number of siblings, IQ test score at age 18, height at age 18, a quadratic in BMI at age 18, a dummy variable for whether the person was born in Norway, month of birth dummies, plant size in the base year (number of employees), a quadratic in tenure in the base year, the average of the $\log$ real earnings from $t=$ 
-5 to $t=-1$, dummies for county of residence in the base year, 1-digit industry dummies for the base year industry. Displacement occurs between 0 and 1. Robust Standard Errors in Parentheses.

* implies statistically significant at the $10 \%$ level; ** implies statistically significant at the $5 \%$ level. 
Table 2B: Effect of Displacement on Outcomes (Women)

\begin{tabular}{|c|c|c|c|c|}
\hline Time & Cholesterol & Blood Pressure & Smoking & Framingham Index \\
\hline-5 & $\begin{array}{c}-.002 \\
(.049) \\
{[9512]}\end{array}$ & $\begin{array}{c}-.600 \\
(.624) \\
{[9578]}\end{array}$ & $\begin{array}{c}.002 \\
(.024) \\
{[9581]}\end{array}$ & $\begin{array}{c}-.029 \\
(.226) \\
{[9511]}\end{array}$ \\
\hline-4 & $\begin{array}{c}.046 \\
(.042) \\
{[11154]}\end{array}$ & $\begin{array}{c}-.132 \\
(.573) \\
{[11217]}\end{array}$ & $\begin{array}{c}.028 \\
(.021) \\
{[11222]}\end{array}$ & $\begin{array}{c}.244 \\
(.192) \\
{[11152]}\end{array}$ \\
\hline-3 & $\begin{array}{c}-.039 \\
(.037) \\
{[12587]}\end{array}$ & $\begin{array}{c}.043 \\
(.518) \\
{[12647]}\end{array}$ & $\begin{array}{c}.010 \\
(.019) \\
{[12652]}\end{array}$ & $\begin{array}{c}-.085 \\
(.176) \\
{[12583]}\end{array}$ \\
\hline-2 & $\begin{array}{c}.007 \\
(.036) \\
{[14033]}\end{array}$ & $\begin{array}{c}.452 \\
(.519) \\
{[14102]}\end{array}$ & $\begin{array}{c}.011 \\
(.018) \\
{[14103]}\end{array}$ & $\begin{array}{c}.165 \\
(.173) \\
{[14026]}\end{array}$ \\
\hline-1 & $\begin{array}{c}-.036 \\
(.034) \\
{[15054]}\end{array}$ & $\begin{array}{c}-.254 \\
(.494) \\
{[15128]}\end{array}$ & $\begin{array}{c}-.011 \\
(.018) \\
{[15118]}\end{array}$ & $\begin{array}{c}-.138 \\
(.163) \\
{[15036]}\end{array}$ \\
\hline 0 & $\begin{array}{c}.010 \\
(.031) \\
{[16744]}\end{array}$ & $\begin{array}{c}-.294 \\
(.419) \\
{[16809]}\end{array}$ & $\begin{array}{c}.015 \\
(.016) \\
{[16773]}\end{array}$ & $\begin{array}{c}.141 \\
(.145) \\
{[16697]}\end{array}$ \\
\hline 1 & $\begin{array}{c}.068^{* *} \\
(.032) \\
{[17725]}\end{array}$ & $\begin{array}{c}-.075 \\
(.444) \\
{[17792]}\end{array}$ & $\begin{array}{c}.034^{* *} \\
(.016) \\
{[17729]}\end{array}$ & $\begin{array}{l}.413 * * \\
(.149) \\
{[17648]}\end{array}$ \\
\hline 2 & $\begin{array}{c}.042 \\
(.032) \\
{[17607]}\end{array}$ & $\begin{array}{c}.216 \\
(.427) \\
{[17667]}\end{array}$ & $\begin{array}{c}.053 * * \\
(.015) \\
{[17600]}\end{array}$ & $\begin{array}{l}.480^{* *} \\
(.143) \\
{[17528]}\end{array}$ \\
\hline 3 & $\begin{array}{c}.024 \\
(.030) \\
{[17296]}\end{array}$ & $\begin{array}{c}.283 \\
(.401) \\
{[17379]}\end{array}$ & $\begin{array}{c}.016 \\
(.014) \\
{[17302]}\end{array}$ & $\begin{array}{c}.107 \\
(.139) \\
{[17212]}\end{array}$ \\
\hline 4 & $\begin{array}{c}.080 * * \\
(.032) \\
{[15542]}\end{array}$ & $\begin{array}{c}-.683 \\
(.428) \\
{[15589]}\end{array}$ & $\begin{array}{c}.030^{* *} \\
(.015) \\
{[15514]}\end{array}$ & $\begin{array}{l}.270^{*} \\
(.142) \\
{[15457]}\end{array}$ \\
\hline 5 & $\begin{array}{c}.033 \\
(.031) \\
{[13964]}\end{array}$ & $\begin{array}{c}-.425 \\
(.444) \\
{[13988]}\end{array}$ & $\begin{array}{c}.024 \\
(.016) \\
{[13916]}\end{array}$ & $\begin{array}{c}.210 \\
(.148) \\
{[13882]}\end{array}$ \\
\hline 6 & $\begin{array}{c}.016 \\
(.034) \\
{[12479]}\end{array}$ & $\begin{array}{c}-.908^{*} \\
(.416) \\
{[12503]}\end{array}$ & $\begin{array}{c}.012 \\
(.017) \\
{[12433]}\end{array}$ & $\begin{array}{c}.046 \\
(.156) \\
{[12401]}\end{array}$ \\
\hline 7 & $\begin{array}{c}.045 \\
(.037) \\
{[10998]}\end{array}$ & $\begin{array}{c}-1.10 * * \\
(.486) \\
{[11028]}\end{array}$ & $\begin{array}{c}.013 \\
(.018) \\
{[10954]}\end{array}$ & $\begin{array}{c}.080 \\
(.168) \\
{[10916]}\end{array}$ \\
\hline
\end{tabular}

All coefficients come from separate regressions with the full set of control variables. The control variables are the same as in Table 2A.

Displacement occurs between 0 and 1. Robust Standard Errors in Parentheses.

* implies statistically significant at the $10 \%$ level; ** implies statistically significant at the $5 \%$ level. 
Table 3A: Effect of Displacement on Heart Risk of Men Means by Time Relative to Displacement

Cholesterol

\begin{tabular}{|c|c|c|c|c|}
\hline & $-5--1$ & $0-1$ & $2-4$ & $5-7$ \\
\hline Not Displaced & $\begin{array}{c}5.81 \\
(0.005) \\
{[161738]}\end{array}$ & $\begin{array}{c}5.80 \\
(0.005) \\
{[97016]}\end{array}$ & $\begin{array}{c}5.78 \\
(0.005) \\
{[146409]}\end{array}$ & $\begin{array}{c}5.78 \\
(0.005) \\
{[109877]}\end{array}$ \\
\hline Displaced & $\begin{array}{c}5.81 \\
(0.012) \\
{[8963]}\end{array}$ & $\begin{array}{c}5.82 \\
(0.013) \\
{[6473]}\end{array}$ & $\begin{array}{c}5.83 \\
(0.010) \\
{[11548]}\end{array}$ & $\begin{array}{c}5.79 \\
(0.011) \\
{[9737]}\end{array}$ \\
\hline \multicolumn{5}{|c|}{ Blood Pressure } \\
\hline & $-5--1$ & $0-1$ & $2-4$ & $5-7$ \\
\hline Not Displaced & $\begin{array}{c}135.23 \\
(0.066) \\
{[162552]}\end{array}$ & $\begin{array}{l}134.40 \\
(0.059) \\
{[97307]}\end{array}$ & $\begin{array}{c}133.92 \\
(0.057) \\
{[146675]}\end{array}$ & $\begin{array}{c}133.55 \\
(0.066) \\
{[109804]}\end{array}$ \\
\hline Displaced & $\begin{array}{l}135.01 \\
(0.141) \\
{[8999]}\end{array}$ & $\begin{array}{l}134.79 \\
(0.170) \\
{[6507]}\end{array}$ & $\begin{array}{l}133.94 \\
(0.126) \\
{[11609]}\end{array}$ & $\begin{array}{l}133.84 \\
(0.137) \\
{[9730]}\end{array}$ \\
\hline \multicolumn{5}{|c|}{ Smoking } \\
\hline & $-5--1$ & $0-1$ & $2-4$ & $5-7$ \\
\hline Not Displaced & $\begin{array}{c}.412 \\
(0.002) \\
{[162835]}\end{array}$ & $\begin{array}{c}.392 \\
(0.002) \\
{[97209]}\end{array}$ & $\begin{array}{c}.383 \\
(0.002) \\
{[146432]}\end{array}$ & $\begin{array}{c}.367 \\
(0.002) \\
{[109467]}\end{array}$ \\
\hline Displaced & $\begin{array}{c}.422 \\
(0.005) \\
{[9015]}\end{array}$ & $\begin{array}{c}.427 \\
(0.006) \\
{[6507]}\end{array}$ & $\begin{array}{c}.426 \\
(0.005) \\
{[11599]}\end{array}$ & $\begin{array}{c}.406 \\
(0.005) \\
{[9723]}\end{array}$ \\
\hline \multicolumn{5}{|c|}{ Framingham Index } \\
\hline & $-5--1$ & $0-1$ & $2-4$ & $5-7$ \\
\hline Not Displaced & $\begin{array}{c}7.57 \\
(0.016) \\
{[161622]}\end{array}$ & $\begin{array}{c}7.42 \\
(0.014) \\
{[96661]}\end{array}$ & $\begin{array}{c}7.34 \\
(0.014) \\
{[145742]}\end{array}$ & $\begin{array}{c}7.25 \\
(0.015) \\
{[109208]}\end{array}$ \\
\hline Displaced & $\begin{array}{c}7.60 \\
(0.030) \\
{[8953]}\end{array}$ & $\begin{array}{c}7.63 \\
(0.040) \\
{[6455]}\end{array}$ & $\begin{array}{c}7.61 \\
(0.030) \\
{[11508]}\end{array}$ & $\begin{array}{c}7.46 \\
(0.032) \\
{[9698]}\end{array}$ \\
\hline
\end{tabular}

Robust Standard Errors in Parentheses allow for repeated observations on individuals. Sample sizes in brackets. 
Table 3B: Effect of Displacement on Heart Risk of Women Means by Time Relative to Displacement

Cholesterol

\begin{tabular}{|c|c|c|c|c|}
\hline & $-5--1$ & $0-1$ & $2-4$ & $5-7$ \\
\hline Not Displaced & $\begin{array}{c}5.41 \\
(0.008) \\
{[59028]}\end{array}$ & $\begin{array}{c}5.41 \\
(0.007) \\
{[32442]}\end{array}$ & $\begin{array}{c}5.42 \\
(0.007) \\
{[47020]}\end{array}$ & $\begin{array}{c}5.44 \\
(0.008) \\
{[34699]}\end{array}$ \\
\hline Displaced & $\begin{array}{c}5.41 \\
(0.017) \\
{[3312]}\end{array}$ & $\begin{array}{c}5.46 \\
(0.022) \\
{[2027]}\end{array}$ & $\begin{array}{c}5.47 \\
(0.018) \\
{[3425]}\end{array}$ & $\begin{array}{c}5.48 \\
(0.019) \\
{[2742]}\end{array}$ \\
\hline \multicolumn{5}{|c|}{ Blood Pressure } \\
\hline & $-5--1$ & $0-1$ & $2-4$ & $5-7$ \\
\hline Not Displaced & $\begin{array}{c}125.33 \\
(0.110) \\
{[59342]}\end{array}$ & $\begin{array}{l}124.47 \\
(0.104) \\
{[32557]}\end{array}$ & $\begin{array}{l}123.96 \\
(0.102) \\
{[47173]}\end{array}$ & $\begin{array}{l}123.91 \\
(0.122) \\
{[34751]}\end{array}$ \\
\hline Displaced & $\begin{array}{l}125.06 \\
(0.236) \\
{[3330]}\end{array}$ & $\begin{array}{l}124.60 \\
(0.298) \\
{[2044]}\end{array}$ & $\begin{array}{c}124 \\
(0.238) \\
{[3462]}\end{array}$ & $\begin{array}{l}123.69 \\
(0.265) \\
{[2760]}\end{array}$ \\
\hline \multicolumn{5}{|c|}{ Smoking } \\
\hline & $-5--1$ & $0-1$ & $2-4$ & $5-7$ \\
\hline Not Displaced & $\begin{array}{c}.461 \\
(0.004) \\
{[59345]}\end{array}$ & $\begin{array}{c}.457 \\
(0.004) \\
{[32459]}\end{array}$ & $\begin{array}{c}.449 \\
(0.004) \\
{[46965]}\end{array}$ & $\begin{array}{c}.434 \\
(0.004) \\
{[34553]}\end{array}$ \\
\hline Displaced & $\begin{array}{c}.479 \\
(0.010) \\
{[3331]}\end{array}$ & $\begin{array}{c}.498 \\
(0.011) \\
{[2043]}\end{array}$ & $\begin{array}{c}.502 \\
(0.009) \\
{[3451]}\end{array}$ & $\begin{array}{c}.485 \\
(0.010) \\
{[2750]}\end{array}$ \\
\hline \multicolumn{5}{|c|}{ Framingham Index } \\
\hline & $-5--1$ & $0-1$ & $2-4$ & $5-7$ \\
\hline Not Displaced & $\begin{array}{c}9.28 \\
(0.037) \\
{[58999]}\end{array}$ & $\begin{array}{c}9.19 \\
(0.035) \\
{[32322]}\end{array}$ & $\begin{array}{c}9.12 \\
(0.034) \\
{[46785]}\end{array}$ & $\begin{array}{c}9.08 \\
(0.039) \\
{[34468]}\end{array}$ \\
\hline Displaced & $\begin{array}{c}9.38 \\
(0.81) \\
{[3309]}\end{array}$ & $\begin{array}{c}9.64 \\
(0.104) \\
{[2023]}\end{array}$ & $\begin{array}{c}9.56 \\
(0.082) \\
{[3412]}\end{array}$ & $\begin{array}{c}9.49 \\
(0.090) \\
{[2731]}\end{array}$ \\
\hline
\end{tabular}

Robust Standard Errors in Parentheses allow for repeated observations on individuals. Sample sizes in brackets. 
Table 4A: Effect of Displacement on Heart Risk of Men

Difference-in-Difference Estimates with controls

\begin{tabular}{|c|c|c|c|c|}
\hline Dependent Variable & Displaced & $\begin{array}{l}\text { Displaced* } \\
\text { Period1 }\end{array}$ & $\begin{array}{l}\text { Displaced* } \\
\text { Period2 }\end{array}$ & $\begin{array}{l}\text { Displaced* } \\
\text { Period3 }\end{array}$ \\
\hline $\begin{array}{l}\text { Cholesterol } \\
(551761)\end{array}$ & $\begin{array}{l}.003 \\
(.013)\end{array}$ & $\begin{array}{l}.006 \\
(.018)\end{array}$ & $\begin{array}{l}.021 \\
(.016)\end{array}$ & $\begin{array}{l}-.003 \\
(.017)\end{array}$ \\
\hline $\begin{array}{l}\text { Blood Pressure } \\
(553183)\end{array}$ & $\begin{array}{l}-.063 \\
(.155)\end{array}$ & $\begin{array}{l}.223 \\
(.222)\end{array}$ & $\begin{array}{l}.067 \\
(.192)\end{array}$ & $\begin{array}{l}.044 \\
(.206)\end{array}$ \\
\hline $\begin{array}{l}\text { Smoking } \\
(552787)\end{array}$ & $\begin{array}{l}.009 \\
(.006)\end{array}$ & $\begin{array}{l}.011 \\
(.008)\end{array}$ & $\begin{array}{l}.018 * * \\
(.007)\end{array}$ & $\begin{array}{l}.016^{* *} \\
(.007)\end{array}$ \\
\hline $\begin{array}{l}\text { Framingham Index } \\
(549847)\end{array}$ & $\begin{array}{l}.042 \\
(.037)\end{array}$ & $\begin{array}{l}.077 \\
(.051)\end{array}$ & $\begin{array}{l}.114^{* *} \\
(.045)\end{array}$ & $\begin{array}{l}.075 \\
(.048)\end{array}$ \\
\hline $\begin{array}{l}\text { Sickness Benefit } \\
(536645)\end{array}$ & $\begin{array}{l}.005 * * \\
(.002)\end{array}$ & $\begin{array}{l}.013 * * \\
(.003)\end{array}$ & $\begin{array}{l}.001 \\
(.003)\end{array}$ & $\begin{array}{l}.001 \\
(.002)\end{array}$ \\
\hline $\begin{array}{l}\text { Disability Benefit } \\
\text { (535784) }\end{array}$ & $\begin{array}{l}-.001 \\
(.001)\end{array}$ & $\begin{array}{l}.001 \\
(.001)\end{array}$ & $\begin{array}{l}.002 * \\
(.001)\end{array}$ & $\begin{array}{l}.002 \\
(.002)\end{array}$ \\
\hline $\begin{array}{l}\text { Body Mass Index } \\
(554440)\end{array}$ & $\begin{array}{l}.048 \\
(.033)\end{array}$ & $\begin{array}{c}-.121 * * \\
(.047)\end{array}$ & $\begin{array}{l}-.023 \\
(.041)\end{array}$ & $\begin{array}{l}-.042 \\
(.044)\end{array}$ \\
\hline $\begin{array}{l}\text { Alternative Index } \\
(536050)\end{array}$ & $\begin{array}{c}.459 \\
(.616)\end{array}$ & $\begin{array}{l}1.42 \\
(.90)\end{array}$ & $\begin{array}{c}2.36^{* *} \\
(.80)\end{array}$ & $\begin{array}{l}.555 \\
(.805)\end{array}$ \\
\hline
\end{tabular}

Each row represents one regression. The control variables include base year dummies, survey dummies, survey month dummies, age at health measurement, a dummy for whether the person is married in the base year, years of education at the base year, birth order dummies, dummies for number of siblings, IQ test score at age 18, height at age 18, a quadratic in BMI at age 18, a dummy variable for whether the person was born in Norway, month of birth dummies, plant size in the base year (number of employees), a quadratic in tenure in the base year, the average of the $\log$ real earnings from $t=-5$ to $t=-1$, dummies for county of residence in the base year, 1-digit industry dummies for the base year industry. Displacement occurs between 0 and 1. Robust Standard Errors in Parentheses allow for repeated observations on individuals. Sample sizes in brackets.

* implies statistically significant at the $10 \%$ level; ** implies statistically significant at the $5 \%$ level. 
Table 4B: Effect of Displacement on Heart Risk of Women

Difference-in-Difference Estimates with controls

\begin{tabular}{|c|c|c|c|c|}
\hline Dependent Variable & Displaced & Displaced $* \mathrm{G} 1$ & Displaced $* \mathrm{G} 2$ & Displaced*G3 \\
\hline $\begin{array}{l}\text { Cholesterol } \\
(184695)\end{array}$ & $\begin{array}{l}-.003 \\
(.019)\end{array}$ & $\begin{array}{l}.038 \\
(.028)\end{array}$ & $\begin{array}{l}.048^{*} \\
(.025)\end{array}$ & $\begin{array}{l}.036 \\
(.027)\end{array}$ \\
\hline $\begin{array}{l}\text { Blood Pressure } \\
(185427)\end{array}$ & $\begin{array}{l}-.056 \\
(.259)\end{array}$ & $\begin{array}{l}-.193 \\
(.381)\end{array}$ & $\begin{array}{l}-.006 \\
(.341)\end{array}$ & $\begin{array}{l}-.606 \\
(.371)\end{array}$ \\
\hline $\begin{array}{l}\text { Smoking } \\
(184897)\end{array}$ & $\begin{array}{l}.008 \\
(.009)\end{array}$ & $\begin{array}{l}.015 \\
(.014)\end{array}$ & $\begin{array}{l}.026 * * \\
(.012)\end{array}$ & $\begin{array}{l}.017 \\
(.013)\end{array}$ \\
\hline $\begin{array}{l}\text { Framingham Index } \\
\text { (184049) }\end{array}$ & $\begin{array}{l}.039 \\
(.087)\end{array}$ & $\begin{array}{l}.214 \\
(.130)\end{array}$ & $\begin{array}{l}.238 * * \\
(.115)\end{array}$ & $\begin{array}{l}.143 \\
(.124)\end{array}$ \\
\hline $\begin{array}{l}\text { Sickness Benefit } \\
\text { (179494) }\end{array}$ & $\begin{array}{l}.003 \\
(.004)\end{array}$ & $\begin{array}{l}.009 \\
(.007)\end{array}$ & $\begin{array}{l}.007 \\
(.006)\end{array}$ & $\begin{array}{l}-.001 \\
(.006)\end{array}$ \\
\hline $\begin{array}{l}\text { Disability Benefit } \\
\text { (179096) }\end{array}$ & $\begin{array}{l}-.002 \\
(.001)\end{array}$ & $\begin{array}{l}.002 \\
(.003)\end{array}$ & $\begin{array}{l}.000 \\
(.003)\end{array}$ & $\begin{array}{l}.007 \\
(.004)\end{array}$ \\
\hline $\begin{array}{l}\text { Body Mass Index } \\
(185293)\end{array}$ & $\begin{array}{l}.030 \\
(.069)\end{array}$ & $\begin{array}{l}-.028 \\
(.108)\end{array}$ & $\begin{array}{l}.053 \\
(.093)\end{array}$ & $\begin{array}{l}.090 \\
(.104)\end{array}$ \\
\hline $\begin{array}{l}\text { Alternative Index } \\
(181605)\end{array}$ & $\begin{array}{l}.106 \\
(.126)\end{array}$ & $\begin{array}{l}.110 \\
(.179)\end{array}$ & $\begin{array}{l}.472 * * \\
(.181)\end{array}$ & $\begin{array}{l}-.001 \\
(.183)\end{array}$ \\
\hline
\end{tabular}

Each row represents one regression. The control variables include base year dummies, survey dummies, survey month dummies, age at health measurement, a dummy for whether the person is married in the base year, years of education at the base year, birth order dummies, dummies for number of siblings, a dummy variable for whether the person was born in Norway, month of birth dummies, plant size in the base year (number of employees), a quadratic in tenure in the base year, the average of the log real earnings from $t=-5$ to $t=-1$, dummies for county of residence in the base year, 1-digit industry dummies for the base year industry. Displacement occurs between 0 and 1. Robust Standard Errors in Parentheses allow for repeated observations on individuals. Sample sizes in brackets.

* implies statistically significant at the $10 \%$ level; ** implies statistically significant at the $5 \%$ level. 
Table 5: Effects by Type of Displacement (Framingham Index only)

Difference-in-Difference Estimates with controls

Men

Displaced Displaced*G1 Displaced*G2 Displaced*G3

\begin{tabular}{|c|c|c|c|c|}
\hline $\begin{array}{l}\text { Downsizings only } \\
\text { (442394) }\end{array}$ & $\begin{array}{l}.045 \\
(.048)\end{array}$ & $\begin{array}{l}.019 \\
(.068)\end{array}$ & $\begin{array}{l}.069 \\
(.060)\end{array}$ & $\begin{array}{l}.042 \\
(.065)\end{array}$ \\
\hline $\begin{array}{l}\text { Plant Closings Only } \\
(438696)\end{array}$ & $\begin{array}{l}.075 \\
(.057)\end{array}$ & $\begin{array}{l}.141 * \\
(.079)\end{array}$ & $\begin{array}{l}.168 * * \\
(.067)\end{array}$ & $\begin{array}{l}.104 \\
(.072)\end{array}$ \\
\hline $\begin{array}{l}\text { Same Firm Displaced } \\
\text { Excluded (545656) }\end{array}$ & $\begin{array}{l}.040 \\
(.038)\end{array}$ & $\begin{array}{l}.116^{* *} \\
(.054)\end{array}$ & $\begin{array}{l}.133^{* *} \\
(.048)\end{array}$ & $\begin{array}{l}.117 * * \\
(.051)\end{array}$ \\
\hline $\begin{array}{l}\text { Same Firm Displaced } \\
\text { Excluded and Plant } \\
\text { Closings Only } \\
(438045)\end{array}$ & $\begin{array}{l}.050 \\
(.059)\end{array}$ & $\begin{array}{l}.173 * * \\
(.080)\end{array}$ & $\begin{array}{l}.192 * * \\
(.070)\end{array}$ & $\begin{array}{l}.136 * * \\
(.074)\end{array}$ \\
\hline
\end{tabular}

\section{Women}

Displaced Displaced*G1 Displaced*G2 Displaced*G3

\begin{tabular}{lcccc}
\hline $\begin{array}{l}\text { Downsizings only } \\
(144512)\end{array}$ & .110 & .128 & -.024 & -.045 \\
& $(.118)$ & $(.176)$ & $(.156)$ & $(.171)$ \\
$\begin{array}{l}\text { Plant Closings Only } \\
(143893)\end{array}$ & -.086 & $.328^{*}$ & $.535^{* *}$ & $.390^{* *}$ \\
& $(.134)$ & $(.193)$ & $(.168)$ & $(.179)$ \\
$\begin{array}{l}\text { Same Firm Displaced } \\
\text { excluded(183140) }\end{array}$ & .036 & $.254^{*}$ & $.255^{* *}$ & .162 \\
$\begin{array}{l}\text { Same Firm Displaced } \\
\text { excluded and Plant }\end{array}$ & $(.090)$ & $(.135)$ & $(.119)$ & $(.129)$ \\
$\begin{array}{l}\text { Closings Only } \\
(143763)\end{array}$ & -.111 & $.413^{* *}$ & $.542^{* *}$ & $.430^{* *}$ \\
\hline
\end{tabular}

Each row represents one regression. The control variables include base year dummies, survey dummies, survey month dummies, age at health measurement, a dummy for whether the person is married in the base year, years of education at the base year, birth order dummies, dummies for number of siblings, IQ test score at age 18, height at age 18, a quadratic in BMI at age 18, a dummy variable for whether the person was born in Norway, month of birth dummies, plant size in the base year (number of employees), a quadratic in tenure in the base year, the average of the $\log$ real earnings from $t=-5$ to $t=-1$, dummies for county of residence in the base year, 1 -digit industry dummies for the base year industry. Displacement occurs between 0 and 1. Robust Standard Errors in Parentheses allow for repeated observations on individuals. Sample sizes in brackets.

* implies statistically significant at the $10 \%$ level; ** implies statistically significant at the $5 \%$ level. 
Table 6A: Intention to Treat Effects for Men

Difference-in-Difference Estimates with controls

\begin{tabular}{|c|c|c|c|c|}
\hline Dependent Variable & Displaced & $\begin{array}{l}\text { Displaced* } \\
\text { Period } 1\end{array}$ & $\begin{array}{l}\text { Displaced* } \\
\text { Period2 }\end{array}$ & $\begin{array}{l}\text { Displaced* } \\
\text { Period3 }\end{array}$ \\
\hline $\begin{array}{l}\text { Cholesterol } \\
(495213)\end{array}$ & $\begin{array}{l}.014 \\
(.012)\end{array}$ & $\begin{array}{l}.007 \\
(.016)\end{array}$ & $\begin{array}{l}-.007 \\
(.015)\end{array}$ & $\begin{array}{l}-.006 \\
(.015)\end{array}$ \\
\hline $\begin{array}{l}\text { Blood Pressure } \\
(496380)\end{array}$ & $\begin{array}{l}-.063 \\
(.149)\end{array}$ & $\begin{array}{l}.440 * * \\
(.206)\end{array}$ & $\begin{array}{l}.173 \\
(.179)\end{array}$ & $\begin{array}{l}.254 \\
(.189)\end{array}$ \\
\hline $\begin{array}{l}\text { Smoking } \\
(495930)\end{array}$ & $\begin{array}{l}.006 \\
(.005)\end{array}$ & $\begin{array}{l}.016^{* *} \\
(.007)\end{array}$ & $\begin{array}{l}.017 * * \\
(.007)\end{array}$ & $\begin{array}{l}.011^{*} \\
(.007)\end{array}$ \\
\hline $\begin{array}{l}\text { Framingham Index } \\
\text { (493399) }\end{array}$ & $\begin{array}{l}.050 \\
(.036)\end{array}$ & $\begin{array}{l}.116^{* *} \\
(.048)\end{array}$ & $\begin{array}{l}.067 \\
(.042)\end{array}$ & $\begin{array}{l}.049 \\
(.045)\end{array}$ \\
\hline $\begin{array}{l}\text { Sickness Benefit } \\
(481301)\end{array}$ & $\begin{array}{l}.002 \\
(.002)\end{array}$ & $\begin{array}{l}.006 * * \\
(.003)\end{array}$ & $\begin{array}{l}.005 * * \\
(.003)\end{array}$ & $\begin{array}{l}.001 \\
(.003)\end{array}$ \\
\hline $\begin{array}{l}\text { Disability Benefit } \\
(480528)\end{array}$ & $\begin{array}{l}.0001 \\
(.001)\end{array}$ & $\begin{array}{l}-.001 \\
(.001)\end{array}$ & $\begin{array}{l}-.0004 \\
(.001)\end{array}$ & $\begin{array}{l}-.001 \\
(.001)\end{array}$ \\
\hline $\begin{array}{l}\text { Body Mass Index } \\
(497515)\end{array}$ & $\begin{array}{l}.029 \\
(.032)\end{array}$ & $\begin{array}{l}-.041 \\
(.044)\end{array}$ & $\begin{array}{l}-.046 \\
(.039)\end{array}$ & $\begin{array}{l}-.010 \\
(.041)\end{array}$ \\
\hline $\begin{array}{l}\text { Alternative Index } \\
(480785)\end{array}$ & $\begin{array}{l}.684 \\
(.603)\end{array}$ & $\begin{array}{l}1.37 * \\
(.83)\end{array}$ & $\begin{array}{c}1.70 * * \\
(.75)\end{array}$ & $\begin{array}{c}.749 \\
(.749)\end{array}$ \\
\hline
\end{tabular}

Each row represents one regression. The control variables include base year dummies, survey dummies, survey month dummies, age at health measurement, a dummy for whether the person is married in the base year, years of education at the base year, birth order dummies, dummies for number of siblings, IQ test score at age 18, height at age 18, a quadratic in BMI at age 18, a dummy variable for whether the person was born in Norway, month of birth dummies, plant size in the base year (number of employees), a quadratic in tenure in the base year, the average of the $\log$ real earnings from $t=-5$ to $t=-1$, dummies for county of residence in the base year, 1 -digit industry dummies for the base year industry. Displacement occurs between 0 and 1. Robust Standard Errors in Parentheses allow for repeated observations on individuals. Sample sizes in brackets.

* implies statistically significant at the $10 \%$ level; ** implies statistically significant at the $5 \%$ level. 
Table 6B: Intention to Treat Effects for Women

\section{Difference-in-Difference Estimates with controls}

\begin{tabular}{|c|c|c|c|c|}
\hline Dependent Variable & Displaced & Displaced*G1 & Displaced*G2 & Displaced*G3 \\
\hline $\begin{array}{l}\text { Cholesterol } \\
(167566)\end{array}$ & $\begin{array}{l}.003 \\
(.018)\end{array}$ & $\begin{array}{l}.011 \\
(.025)\end{array}$ & $\begin{array}{l}.030 \\
(.023)\end{array}$ & $\begin{array}{l}.011 \\
(.024)\end{array}$ \\
\hline $\begin{array}{l}\text { Blood Pressure } \\
(168181)\end{array}$ & $\begin{array}{l}.395 \\
(.248)\end{array}$ & $\begin{array}{l}-.627 \\
(.348)\end{array}$ & $\begin{array}{l}-.145 \\
(.318)\end{array}$ & $\begin{array}{c}-.822 * * \\
(.340)\end{array}$ \\
\hline $\begin{array}{l}\text { Smoking } \\
(167688)\end{array}$ & $\begin{array}{l}.007 \\
(.009)\end{array}$ & $\begin{array}{l}.012 \\
(.013)\end{array}$ & $\begin{array}{l}.026^{* *} \\
(.011)\end{array}$ & $\begin{array}{l}.016 \\
(.012)\end{array}$ \\
\hline $\begin{array}{l}\text { Framingham Index } \\
\text { (166968) }\end{array}$ & $\begin{array}{l}.100 \\
(.083)\end{array}$ & $\begin{array}{l}.109 \\
(.118)\end{array}$ & $\begin{array}{l}.191 * \\
(.106)\end{array}$ & $\begin{array}{l}.059 \\
(.112)\end{array}$ \\
\hline $\begin{array}{l}\text { Sickness Benefit } \\
(162859)\end{array}$ & $\begin{array}{l}-.001 \\
(.004)\end{array}$ & $\begin{array}{l}-.001 \\
(.006)\end{array}$ & $\begin{array}{l}.004 \\
(.005)\end{array}$ & $\begin{array}{l}.007 \\
(.006)\end{array}$ \\
\hline $\begin{array}{l}\text { Disability Benefit } \\
\text { (162550) }\end{array}$ & $\begin{array}{l}-.002 * \\
(.001)\end{array}$ & $\begin{array}{l}.001 \\
(.002)\end{array}$ & $\begin{array}{l}-.004 \\
(.003)\end{array}$ & $\begin{array}{l}.002 \\
(.004)\end{array}$ \\
\hline $\begin{array}{l}\text { Body Mass Index } \\
\text { (168047) }\end{array}$ & $\begin{array}{l}.109^{*} \\
(.065)\end{array}$ & $\begin{array}{l}-.047 \\
(.098)\end{array}$ & $\begin{array}{l}-.085 \\
(.086)\end{array}$ & $\begin{array}{l}-.087 \\
(.093)\end{array}$ \\
\hline $\begin{array}{l}\text { Alternative Index } \\
\text { (164648) }\end{array}$ & $\begin{array}{l}.093 \\
(.116)\end{array}$ & $\begin{array}{l}.003 \\
(.159)\end{array}$ & $\begin{array}{l}.367 * * \\
(.158)\end{array}$ & $\begin{array}{l}-.040 \\
(1.66)\end{array}$ \\
\hline
\end{tabular}

Each row represents one regression. The control variables include base year dummies, survey dummies, survey month dummies, age at health measurement, a dummy for whether the person is married in the base year, years of education at the base year, birth order dummies, dummies for number of siblings, IQ test score at age 18, height at age 18, a quadratic in BMI at age 18, a dummy variable for whether the person was born in Norway, month of birth dummies, plant size in the base year (number of employees), a quadratic in tenure in the base year, the average of the $\log$ real earnings from $t=-5$ to $t=-1$, dummies for county of residence in the base year, 1-digit industry dummies for the base year industry. Displacement occurs between 0 and 1 . Robust Standard Errors in Parentheses allow for repeated observations on individuals. Sample sizes in brackets.

* implies statistically significant at the $10 \%$ level; ** implies statistically significant at the $5 \%$ level. 
Appendix Table 1: Effect of Displacement on Labor Market Outcomes

\begin{tabular}{|c|c|c|c|c|}
\hline \multirow{2}{*}{ Time } & \multicolumn{2}{|c|}{ Men } & \multicolumn{2}{|c|}{ Women } \\
\hline & Log Earnings & Whether Employed & Log Earnings & Whether Employed \\
\hline \multirow[t]{3}{*}{-5} & 0.000 & $-0.041^{* *}$ & $-0.071 * *$ & -0.001 \\
\hline & $(.009)$ & $(0.010)$ & $(.032)$ & $(0.014)$ \\
\hline & [25110] & [25167] & [9469] & [9582] \\
\hline \multirow[t]{3}{*}{-4} & 0.000 & $-0.013 *$ & 0.009 & $-0.031^{* *}$ \\
\hline & $(0.007)$ & $(0.007)$ & $(0.016)$ & $(0.013)$ \\
\hline & [29564] & [29303] & [11119] & [11224] \\
\hline \multirow[t]{3}{*}{-3} & -0.001 & -0.004 & 0.004 & -0.015 \\
\hline & $(0.006)$ & $(0.005)$ & $(0.012)$ & $(0.010)$ \\
\hline & [33539] & [34517] & [12577] & [12656] \\
\hline \multirow[t]{3}{*}{-2} & -0.006 & $-0.015 * *$ & $-0.019 *$ & $-0.030^{* *}$ \\
\hline & $(0.004)$ & $(0.005)$ & $(0.011)$ & $(0.010)$ \\
\hline & [39484] & [39525] & [14070] & [14110] \\
\hline \multirow[t]{3}{*}{-1} & -0.002 & $0.0002 * *$ & $-0.014 * *$ & $0.0004 *$ \\
\hline & $(0.002)$ & $(0.0001)$ & $(0.006)$ & $(0.0002)$ \\
\hline & [43456] & [43464] & [15133] & [15136] \\
\hline \multirow[t]{3}{*}{0} & $-0.013 * *$ & - & $-0.027 * *$ & - \\
\hline & $(0.005)$ & & $(0.013)$ & \\
\hline & [49474] & [49474] & [16820] & [16820] \\
\hline \multirow[t]{3}{*}{1} & $-0.061^{* *}$ & $-0.178^{* *}$ & $-0.049 * *$ & $-0.176^{* *}$ \\
\hline & $(0.008)$ & $(0.007)$ & $(0.016)$ & $(0.013)$ \\
\hline & [54525] & [54616] & [17729] & [17806] \\
\hline \multirow[t]{3}{*}{2} & $-0.055^{* *}$ & $-0.106^{* *}$ & $-0.060 * *$ & $-0.125^{* *}$ \\
\hline & $(0.007)$ & $(0.006)$ & $(0.018)$ & $(0.012)$ \\
\hline & [55185] & [55411] & [17493] & [17679] \\
\hline \multirow[t]{3}{*}{3} & $-0.048 * *$ & $-0.073 * *$ & $-0.061 * *$ & $-0.076^{* *}$ \\
\hline & $(0.008)$ & $(0.005)$ & $(0.019)$ & $(0.011)$ \\
\hline & [53615] & [53977] & [17087] & [17386] \\
\hline \multirow[t]{3}{*}{4} & $-0.055^{* *}$ & $-0.076^{* *}$ & $-0.087 * *$ & $-0.077 * *$ \\
\hline & $(0.009)$ & $(0.006)$ & $(0.024)$ & $(0.012)$ \\
\hline & [48918] & [49351] & [15245] & [15599] \\
\hline \multirow[t]{3}{*}{5} & $-0.043 * *$ & $-0.063 * *$ & $-0.72 * *$ & $-0.051^{* *}$ \\
\hline & $(0.010)$ & $(0.006)$ & $(0.026)$ & $(0.012)$ \\
\hline & [44448] & [44966] & [13609] & [13998] \\
\hline \multirow[t]{3}{*}{6} & $-0.036 * *$ & $-0.057^{* *}$ & $-0.042 * *$ & $-0.067^{* *}$ \\
\hline & $(0.010)$ & $(0.006)$ & $(0.026)$ & $(0.013)$ \\
\hline & [39827] & [40336] & [12098] & [12511] \\
\hline \multirow[t]{3}{*}{7} & $-0.031 * *$ & $-0.041 * *$ & $-0.095 * *$ & $-0.081 * *$ \\
\hline & $(0.011)$ & $(0.006)$ & $(0.034)$ & $(0.015)$ \\
\hline & [34071] & [34596] & {$[10562]$} & {$[11036]$} \\
\hline
\end{tabular}

All coefficients come from separate regressions with the full set of control variables. The control variables are the same as in Table 2.

Displacement occurs between 0 and 1 . Robust standard errors in parentheses.

* implies statistically significant at the $10 \%$ level; ** implies statistically significant at the $5 \%$ level. 
Appendix Table 2

Coefficients on Selected Other Variables

Dependent Variable is Framingham Index

\begin{tabular}{|c|c|c|}
\hline & Men & Women \\
\hline Married & $\begin{array}{c}-.363 * * \\
(.026)\end{array}$ & $\begin{array}{c}.632 * * \\
(.055)\end{array}$ \\
\hline Education & $\begin{array}{c}-.182 * * \\
(.005)\end{array}$ & $\begin{array}{c}-.394 * * \\
(.013)\end{array}$ \\
\hline Cognitive Score & $\begin{array}{c}-.136^{* *} \\
(.010)\end{array}$ & \\
\hline Height & $\begin{array}{c}-.030 * * \\
(.003)\end{array}$ & \\
\hline BMI & $\begin{array}{l}-.027 \\
(.068)\end{array}$ & \\
\hline BMI Squared & $\begin{array}{c}.002 \\
(.001)\end{array}$ & \\
\hline Native & $\begin{array}{l}.461 * * \\
(.077)\end{array}$ & $\begin{array}{l}1.95 * * \\
(.173)\end{array}$ \\
\hline Plant Size/1000 & $\begin{array}{c}.010 \\
(.028)\end{array}$ & $\begin{array}{c}-.165 * * \\
(.067)\end{array}$ \\
\hline Tenure & $\begin{array}{l}-.009 * \\
(.005)\end{array}$ & $\begin{array}{l}-.011 \\
(.012)\end{array}$ \\
\hline Tenure Squared/100 & $\begin{array}{l}-.005 \\
(.025)\end{array}$ & $\begin{array}{c}.074 \\
(.065)\end{array}$ \\
\hline Prior Average Log Earnings & $\begin{array}{c}-.135 * * \\
(.038)\end{array}$ & $\begin{array}{l}-.008 \\
(.066)\end{array}$ \\
\hline $\mathrm{N}$ & 521395 & 184049 \\
\hline
\end{tabular}

Robust Standard Errors in Parentheses allow for repeated observations on individuals.

* implies statistically significant at the $10 \%$ level; ** implies statistically significant at the $5 \%$ level. 


\section{Appendix Table 3: Robustness Checks (Framingham Index only)}

Men

\begin{tabular}{lcccc}
\hline & Displaced & Displaced*G1 & Displaced*G2 & Displaced*G3 \\
\hline $\begin{array}{l}\text { Control Group 2 } \\
(486335)\end{array}$ & .050 & .078 & $.111^{* *}$ & .069 \\
& $(.037)$ & $(.052)$ & $(.046)$ & $(.049)$ \\
$\begin{array}{l}\text { Control Group 3 } \\
(332038)\end{array}$ & .017 & .088 & $.146^{* *}$ & $.128^{* *}$ \\
& $(.040)$ & $(.052)$ & $(.047)$ & $(.051)$ \\
$\begin{array}{l}\text { Propensity Score Weighting } \\
(549847)\end{array}$ & .042 & .078 & $.118^{* *}$ & .069 \\
$\begin{array}{l}\text { Propensity Score Screening } \\
(.02-.15)\end{array}$ & $(.037)$ & $(.052)$ & $(.046)$ & $(.049)$ \\
$\begin{array}{l}(533367) \\
\text { Propensity Score Screening }\end{array}$ & $(.037)$ & $.086 *$ & $.107 * *$ & .076 \\
$\begin{array}{l}(.03-.10) \\
(415765)\end{array}$ & $(.041)$ & $(.052)$ & $(.047)$ & $(.050)$ \\
\hline
\end{tabular}

\section{Women}

\section{Displaced $\quad$ Displaced*G1 $\quad$ Displaced*G2 $\quad$ Displaced*G3}

\begin{tabular}{|c|c|c|c|c|}
\hline $\begin{array}{l}\text { Control Group } 2 \\
(164476)\end{array}$ & $\begin{array}{l}.057 \\
(.088)\end{array}$ & $\begin{array}{l}.220^{*} \\
(.130)\end{array}$ & $\begin{array}{l}.237 * * \\
(.116)\end{array}$ & $\begin{array}{l}.115 \\
(.125)\end{array}$ \\
\hline $\begin{array}{l}\text { Control Group } 3 \\
\text { (116652) }\end{array}$ & $\begin{array}{l}.058 \\
(.092)\end{array}$ & $\begin{array}{l}.211 \\
(.132)\end{array}$ & $\begin{array}{l}.249 * * \\
(.119)\end{array}$ & $\begin{array}{l}.125 \\
(.130)\end{array}$ \\
\hline $\begin{array}{l}\text { Propensity Score Weighting } \\
(184044)\end{array}$ & $\begin{array}{l}.060 \\
(.087)\end{array}$ & $\begin{array}{l}.214 \\
(.131)\end{array}$ & $\begin{array}{l}.202^{*} \\
(.117)\end{array}$ & $\begin{array}{l}.076 \\
(.125)\end{array}$ \\
\hline $\begin{array}{l}\text { Propensity Score Screening }(.02-.15) \\
(179469)\end{array}$ & $\begin{array}{l}.033 \\
(.088)\end{array}$ & $\begin{array}{l}.252 * \\
(.132)\end{array}$ & $\begin{array}{l}.263 * * \\
(.118)\end{array}$ & $\begin{array}{l}.150 \\
(.127)\end{array}$ \\
\hline $\begin{array}{l}\text { Propensity Score Screening }(.03-.10) \\
(143757)\end{array}$ & $\begin{array}{l}.040 \\
(.098)\end{array}$ & $\begin{array}{l}.293 * * \\
(.147)\end{array}$ & $\begin{array}{l}.396 * * \\
(.136)\end{array}$ & $\begin{array}{l}.033 \\
(.148) \\
\end{array}$ \\
\hline $\begin{array}{l}\text { Each row represents one regressio } \\
\text { month dummies, age at health mea } \\
\text { of education at the base year, birth } \\
\text { height at age 18, a quadratic in BN } \\
\text { month of birth dummies, plant size } \\
\text { year, the average of the log real ea } \\
\text { 1-digit industry dummies for the b } \\
\text { Errors in Parentheses allow for rep } \\
* \text { imnlies }\end{array}$ & $\begin{array}{l}\text { age } 18, \\
\text { the base } \\
\text { gs from } \\
\text { year ind }\end{array}$ & $\begin{array}{l}\text { y variabl } \\
\text { mber of } \\
t=-1, d \\
\text { splaceme }\end{array}$ & $\begin{array}{l}\text { Ir dummie } \\
\text { son is mar } \\
\text { f siblings, } \\
\text { ner the per } \\
\text {, a quadra } \\
\text { county of } \\
\text { petween } 0 \\
\text { le sizes in }\end{array}$ & $\begin{array}{l}\text { lummies, survey } \\
\text { base year, years } \\
\text { re at age } 18, \\
\text { orn in Norway, } \\
\text { lre in the base } \\
\text { in the base year, } \\
\text { bust Standard }\end{array}$ \\
\hline
\end{tabular}


Appendix Table 4: Heterogeneous Effects (Framingham Index only)

Heterogeneous Effects

MEN

\begin{tabular}{|c|c|c|c|c|}
\hline & Displaced & Displaced*G1 & Displaced*G2 & Displaced*G3 \\
\hline $\begin{array}{l}\text { Education } \geq 12 \\
{[257484]}\end{array}$ & $\begin{array}{c}.010 \\
(.008)\end{array}$ & $\begin{array}{c}.014 \\
(.010)\end{array}$ & $\begin{array}{c}.012 \\
(.010)\end{array}$ & $\begin{array}{c}.006 \\
(.011)\end{array}$ \\
\hline $\begin{array}{l}\text { Education }<12 \\
{[295303]}\end{array}$ & $\begin{array}{c}.008 \\
(.008)\end{array}$ & $\begin{array}{c}.008 \\
(.011)\end{array}$ & $\begin{array}{l}.021 * * \\
(.010)\end{array}$ & $\begin{array}{l}.022 * * \\
(.011)\end{array}$ \\
\hline $\begin{array}{l}\text { Tenure } \geq 7.5 \\
{[275494]}\end{array}$ & $\begin{array}{l}.005 \\
(.008)\end{array}$ & $\begin{array}{l}-.001 \\
(.012)\end{array}$ & $\begin{array}{l}.010 \\
(.011)\end{array}$ & $\begin{array}{l}.016 \\
(.012)\end{array}$ \\
\hline $\begin{array}{l}\text { Tenure }<7.5 \\
{[277293]}\end{array}$ & $\begin{array}{l}.013 \\
(.008)\end{array}$ & $\begin{array}{l}.019^{*} \\
(.011)\end{array}$ & $\begin{array}{l}.021 * * \\
(.010)\end{array}$ & $\begin{array}{l}.012 \\
(.010)\end{array}$ \\
\hline $\begin{array}{l}\text { Firm Size } \geq 100 \\
{[235972]}\end{array}$ & $\begin{array}{l}.012 \\
(.009)\end{array}$ & $\begin{array}{l}.002 \\
(.012)\end{array}$ & $\begin{array}{l}.010 \\
(.011)\end{array}$ & $\begin{array}{l}.000 \\
(.011)\end{array}$ \\
\hline $\begin{array}{l}\text { Firm Size }<100 \\
{[316815]}\end{array}$ & $\begin{array}{l}.005 \\
(.007)\end{array}$ & $\begin{array}{l}.019^{*} \\
(.011)\end{array}$ & $\begin{array}{l}.026^{* *} \\
(.009)\end{array}$ & $\begin{array}{l}.030 * * \\
(.010)\end{array}$ \\
\hline $\begin{array}{l}\text { Married } \\
\text { [395917] }\end{array}$ & $\begin{array}{c}.008 \\
(.006)\end{array}$ & $\begin{array}{l}.012 \\
(.009)\end{array}$ & $\begin{array}{l}.016^{* *} \\
(.008)\end{array}$ & $\begin{array}{c}.014 \\
(.009)\end{array}$ \\
\hline $\begin{array}{l}\text { Unmarried } \\
\text { [129040] }\end{array}$ & $\begin{array}{l}.011 \\
(.012)\end{array}$ & $\begin{array}{l}.007 \\
(.017)\end{array}$ & $\begin{array}{l}.013 \\
(.015)\end{array}$ & $\begin{array}{l}.021 \\
(.016)\end{array}$ \\
\hline
\end{tabular}




\section{WOMEN}

\begin{tabular}{lcccc}
\hline & Displaced & Displaced*G1 & Displaced*G2 & Displaced*G3 \\
\hline Education $\geq 12$ & -.042 & .352 & .154 & -.108 \\
{$[54407]$} & $(.170)$ & $(.255)$ & $(.224)$ & $(.236)$ \\
Education $<12$ & .052 & .167 & $.270^{* *}$ & .222 \\
{$[129642]$} & $(.101)$ & $(.151)$ & $(.135)$ & $(.147)$ \\
\hline Tenure $\geq 7.5$ & .117 & -.032 & .138 & .121 \\
{$[71516]$} & $(.139)$ & $(.225)$ & $(.205)$ & $(.236)$ \\
Tenure $<7.5$ & .000 & $.333^{* *}$ & $.274^{*}$ & .141 \\
{$[112533]$} & $(.111)$ & $(.163)$ & $(.144)$ & $(.151)$ \\
& & & & .057 \\
\hline Firm Size $\geq 100$ & .072 & .190 & .146 & $(.209)$ \\
{$[68406]$} & $(.147)$ & $(.219)$ & $(.198)$ & .195 \\
Firm Size $<100$ & .035 & .206 & $.267^{*}$ & $(.156)$ \\
{$[115643]$} & $(.108)$ & $(.163)$ & $(.143)$ & .127 \\
\hline Married & & & & $(.164)$ \\
{$[116152]$} & .016 & $.342^{* *}$ & .135 & .133 \\
Unmarried & $(.106)$ & $(.161)$ & $(.144)$ & $(.212)$ \\
{$[61350]$} & .073 & -.019 & $.392^{*}$ & $(.203)$ \\
\hline
\end{tabular}

Each row represents one regression. The control variables include base year dummies, survey dummies, survey month dummies, age at health measurement, a dummy for whether the person is married in the base year, years of education at the base year, birth order dummies, dummies for number of siblings, IQ test score at age 18, height at age 18, a quadratic in BMI at age 18, a dummy variable for whether the person was born in Norway, month of birth dummies, plant size in the base year (number of employees), a quadratic in tenure in the base year, the average of the $\log$ real earnings from $t=-5$ to $t=-1$, dummies for county of residence in the base year, 1-digit industry dummies for the base year industry. Displacement occurs between 0 and 1 . Robust Standard Errors in Parentheses allow for repeated observations on individuals. Sample sizes in brackets.

* implies statistically significant at the $10 \%$ level; ** implies statistically significant at the $5 \%$ level. 


\section{Appendix: Heart Risk Indices}

\section{Framingham Risk Score}

To calculate the risk score we use the scale for persons aged 40-49 as most people in our sample are in this age range. Also, we exclude age as a risk factor. We do not have information on HDL cholesterol for most of the sample so we exclude this variable. We assume that people are not having treatment for high blood pressure. Our version of the Framingham risk score is calculated as follows:

Framingham Risk Score for Women

Total cholesterol, mg/dL: Under 160: 0 points. 160-199: 3 points. 200-239: 6 points. 240279: 8 points. 280 or higher: 10 points.

If cigarette smoker: 7 points.

All non smokers: 0 points.

Systolic blood pressure, mm Hg: Under 120: 0 points. 120-129: 1 point. 130-139: 2 points. 140-159: 3 points. 160 or higher: 4 points.

Framingham Risk Score for Men

Total cholesterol, mg/dL: Under 160: 0 points. 160-199: 3 points. 200-239: 5 points. 240279: 6 points. 280 or higher: 8 points.

If cigarette smoker: 5 points.

All non smokers: 0 points.

Systolic blood pressure, mm Hg: Under 120: 0 points. 120-129: 0 points. 130-139: 1 point. 140-159: 1 point. 160 or higher: 2 points.

The point score translates into an estimate of the probability of future coronary heart disease events with higher scores indicating higher probability of disease. For example, for men, 5 points corresponds to approximately a $\% 10$-year risk, 10 points indicates $6 \%$, and 15 points indicates $20 \%$. Equivalent figures for women are $<1 \%, 1 \%$, and $3 \%$.

\section{Westerlund risk of cardiovascular disease}

This variable measures the risk of cardiovascular disease over the next 10 years. The scale is relative to a woman with zero risk characteristics. The mean score for men is 35 which means the average man is 35 times more likely to have cardiovascular disease than a woman with low risk characteristics. The lowest value of 1 is allocated to females who have

1. Systolic Blood Pressure less than 135

2. Non-smoker

3. No family history of heart disease

4. Cholesterol less than 4.91

In contrast, a man with 
1. Systolic Blood pressure of 148

2. Smokes 10 cigarettes a day

3. No family history of heart disease

4. Cholesterol of 5.95

would have a score of $5 * 2 * 2.5 * 1 * 2=50$. Note that this scale is a multiplicative function of blood pressure, smoking behavior, family history of heart disease, and cholesterol. This score has been shown to have an approximately linear relationship with the incidence of death from heart disease in Norway. 